\title{
Characterisation of the relaxin family peptide 3 receptor system in the mouse bed nucleus of the stria terminalis
}

Running title: RXFP3 system in mouse BNST

Authors: Sarah S Ch'ng*, Jingjing Fu*, Robyn M Brown, Craig Smith, Mohammed Akhter Hossain, Stuart J McDougall^, Andrew J Lawrence^

Affiliations: Florey Institute of Neuroscience and Mental Health, Parkville, Victoria, Australia

*These authors contributed equally.

^Corresponding authors:

Florey Institute of Neuroscience and Mental Health

30 Royal Parade, Parkville, Victoria, 3010 Australia

Ph:+61 $383440416 \quad$ stuart.mcdougall@florey.edu.au

Ph:+61 390356692 andrew.lawrence@florey.edu.au

Acknowledgements: These studies were supported by National Health and Medical Research Council (NHMRC) of Australia project grants 1079893 to AJL and 1122170 to MAH. AJL is a NHMRC Principal Research Fellow (1116930). We acknowledge the Victorian State Government Infrastructure Program and useful discussions with A/Professor Andrew Gundlach.

Data Availability Statement: The data that support the findings of this study are available from the corresponding author upon reasonable request.

This is the author manuscript accepted for publication and has undergone full peer review but has not been through the copyediting, typesetting, pagination and proofreading process, which may lead to differences between this version and the Version of Record. Please cite this article as doi: 10.1002/cne.24695

This article is protected by copyright. All rights reserved. 


\section{Abstract:}

The bed nucleus of the stria terminalis (BNST) is a critical node involved in stress and reward-related behaviours. Relaxin family peptide 3 receptor (RXFP3) signalling in the BNST has been implicated in stressinduced alcohol seeking behaviour. However, the neurochemical phenotype and connectivity of BNST RXFP3expressing (RXFP3+) cells have yet to be elucidated. We interrogated the molecular signature and electrophysiological properties of BNST RXFP3+ neurons using a RXFP3-Cre reporter mouse line. BNST RXFP3+ cells are circumscribed to the dorsal BNST (dBNST) and are neurochemically heterogeneous, comprising a mix of inhibitory and excitatory neurons. Immunohistochemistry revealed that $\sim 48 \%$ of BNST RXFP3+ neurons are GABAergic, and a quarter of these co-express the calcium-binding protein, calbindin. A subset of BNST RXFP3+ cells ( 41\%) co-express CaMKIla, suggesting this subpopulation of BNST RXFP3+ neurons are excitatory. Corroborating this, RNAscope ${ }^{\circledR}$ revealed that $\sim 35 \%$ of BNST RXFP3+ cells express vVGluT2 mRNA, indicating a subpopulation of RXFP3+ neurons are glutamatergic. RXFP3+ neurons show direct hyperpolarisation to bath application of a selective RXFP3 agonist, RXFP3-A2, while around 50\% of cells were depolarised by exogenous corticotrophin releasing factor. In behaviourally naive mice the majority of RXFP3+ neurons were type II cells exhibiting $I_{h}$ and $T$ type calcium mediated currents. However, chronic swim stress caused persistent plasticity, decreasing the proportion of neurons that express these channels. These studies are the first to characterise the BNST RXFP3 system in mouse and lay the foundation for future functional studies appraising the role of the murine BNST RXFP3 system in more complex behaviours.

Keywords: Bed nucleus of the stria terminalis, relaxin-3, RXFP3, corticotropin-releasing factor, stress

RRID: MMRRC_036667-UCD, RRID: IMSR_JAX:007914, RRID: AB_300798, RRID: AB_2536183, RRID: $A B \_141607, R R I D: A B \_141844, R R I D: A B \_141637, R R I D: A B \_142672, R R I D: A B \_2336132, R R I D: A B \_477652$, RRID: $A B \_887883$, RRID: AB_477329, RRID: AB_634520, RRID: AB_2619710, RRID: AB_309787, RRID: AB_2340375 


\section{Introduction}

The bed nucleus of the stria terminalis (BNST) is a limbic forebrain region that modulates a range of motivational and affective states (Ch'ng, Fu, Brown, McDougall, \& Lawrence, 2018). The BNST is a critical locus within the neurocircuitry that mediates the dysphoric state during drug withdrawal (Aston-Jones \& Harris, 2004; Koob, 2003), and is crucial for stress-induced relapse to alcohol and drugs of abuse (Briand, Vassoler, Pierce, Valentino, \& Blendy, 2010; Buffalari \& See, 2011; McFarland, Davidge, Lapish, \& Kalivas, 2004). BNST neurons are highly susceptible to stress and drug/alcohol-induced neuroplasticity (Dumont, Mark, Mader, \& Williams, 2005; Silberman, Matthews, \& Winder, 2013). Indeed, altered intrinsic BNST activity and BNST-driven enhancement of activity in reward centres during drug withdrawal may partly underlie its contribution to stress-induced relapse (Hopf et al., 2007; Silberman et al., 2013; Szücs, Berton, Sanna, \& Francesconi, 2012).

The BNST comprises multiple subnuclei with different cytoarchitectural, neurochemical, and hodological attributes (Alheid, 2003; Dong \& Swanson, 2004, 2006; Ju \& Swanson, 1989; Moga, Saper, \& Gray, 1989). Topographically, the rodent BNST is bisected into dorsal (dBNST) and ventral (VBNST) divisions by the anterior commissure. The stria terminalis demarcates medial and lateral subdivisions of the BNST (Paxinos \& Franklin, 2004; Phelix, Liposits, \& Paull, 1992). Emerging evidence suggests that different subregions of the BNST possess divergent roles. The anterolateral BNST (alBNST), which contains a high density of corticotropinreleasing factor (CRF) expressing neurons, is anxiogenic; whereas the anteromedial BNST promotes anxiolysis (Kim et al., 2013). Both the dBNST and vBNST project to the ventral tegmental area (VTA); however, these pathways show divergent but complementary roles in drug consumption, conditioned reinforcement, and drug-seeking behaviour (Briand et al., 2010; Buffalari \& See, 2011; Jennings et al., 2013; Mahler \& Aston-Jones, 2012; Marcinkiewcz et al., 2016; Sartor \& Aston-Jones, 2012).

Various stress-related neuromodulatory and neuropeptide systems, including CRF, noradrenaline, dynorphin, and pituitary adenylate cyclase-activating peptide (PACAP) act within the BNST to affect stressinduced reinstatement of reward-seeking (Di Bonaventura et al., 2014; Erb, Salmaso, Rodaros, \& Stewart, 2001; Erb \& Stewart, 1999; Lê, Funk, Coen, Tamadon, \& Shaham, 2018; Leri, Flores, Rodaros, \& Stewart, 2002; Miles et al., 2017; Vranjkovic, Gasser, Gerndt, Baker, \& Mantsch, 2014; Wang, Fang, Liu, \& Lu, 2006). We have recently discovered a role for the neuropeptide system relaxin-3 and its cognate receptor, relaxin family peptide 3 receptor (RXFP3), in stress-induced relapse to alcohol seeking. Relaxin-3 is a 51-amino acid neuropeptide that is the most recently identified member of the insulin/relaxin superfamily (Bathgate et al., 2002). The relaxin-3 gene is highly conserved across species (Wilkinson, Speed, Tregear, \& Bathgate, 2005). In rats, relaxin-3 is predominantly expressed in GABAergic neurons of the hindbrain nucleus incertus which is 
situated in the midline periventricular central grey (Tanaka et al., 2005). Smaller populations of relaxin-3 neurons are also found in the pontine raphe, periaqueductal gray, and area dorsal to the substantia nigra (Ma et al., 2007; Tanaka et al., 2005). Corroborating these studies in rats, neuroanatomical mapping in mice shows a largely similar distribution of relaxin-3 expression (Smith et al., 2010). In macaques, relaxin-3 is expressed in a group of neurons equivalent to the rodent nucleus incertus (Ma, Sang, Lanciego, \& Gundlach, 2009). These similarities in relaxin-3 expression across different species imply conservation of the relaxin-3 system in the mammalian brain.

The cognate receptor for relaxin-3 is the G-protein coupled receptor, RXFP3, to which it binds with high affinity (Liu et al., 2003). RXFP3 couples to the Gi/o signalling cascade and inhibits cyclic adenosine monophosphate (cAMP) production in cell-based assays (van der Westhuizen, Werry, Sexton, \& Summers, 2007), suggesting that relaxin-3 signalling may confer complimentary inhibitory effects to the primary neurotransmitter (GABA) used by nucleus incertus relaxin-3 neurons. More recent in vitro studies have shown that RXFP3 activation can also stimulate p38MAPK, ERK1/2, and NF- $\kappa B$ signalling cascades (Kocan, Sarwar, Hossain, Wade, \& Summers, 2014). Electrophysiological recordings in rat have demonstrated that RXFP3 activation depolarises neuropeptide Y-expressing neurons within the rat intergeniculate leaflet (Blasiak et al., 2013). Thus, the intracellular effects of RXFP3 signalling appear to be heterogeneous and likely depend on the neurochemistry and connectivity of RXFP3+ neurons.

Nucleus incertus relaxin-3 neurons send widespread efferents throughout the neuraxis, and sites receiving relaxin-3 innervation overlap with those expressing RXFP3 mRNA. Notably, the BNST receives dense relaxin-3 input and expresses an abundance of RXFP3 (Ma et al., 2007; Smith et al., 2010), suggesting that this neuropeptide system modulates behaviours pertinent to stress and reward. Indeed, we have demonstrated that microinjections of a selective RXFP3 antagonist, R3(B1-22)R, directly into the dBNST abolished stressinduced reinstatement of alcohol-seeking in alcohol-preferring rats, without affecting sucrose-seeking (Ryan et al., 2013). This implies a functionally specific role for BNST RXFP3-expressing (RXFP3+) neurons in stressinduced alcohol-seeking. However, the neurochemical phenotype and electrophysiological characteristics of BNST RXFP3+ neurons remain equivocal. Efforts to elucidate the neurochemistry of RXFP3+ neurons have largely been hampered by the paucity of validated antibodies that can reliably detect RXFP3 in brain. In this study, we assessed the neurochemical signature of BNST RXFP3+ neurons in RXFP3-Cre transgenic reporter mice (Gerfen, Paletzki, \& Heintz, 2013) using immunohistochemistry (IHC) and RNAscope . We also characterised the basic electrophysiological properties of BNST RXFP3+ neurons and demonstrate that they exhibit persistent stress-induced plasticity. 


\section{Materials and methods}

\section{$2.1 \quad$ Animals}

All experiments were performed in accordance with the Prevention of Cruelty to Animals Act 1986 under the guidelines of the National Health and Medical Research Council Code of Practice for the Care and Use of Animals for Experimental Purposes in Australia. All experiments were approved by the Animal Ethics Committee of the Florey Institute of Neuroscience and Mental Health (ethics number: 14-035). Two lines of RXFP3-Cre fluorescent reporter mice were used in these studies. The RXFP3-Cre founder strain $(\operatorname{Tg}(\operatorname{Rxfp3}-$ cre)RS38Gsat) was on a mixed background of FVB/N and Crl:CD1(ICR) (obtained from MMRRC/Gensat, stock number 036667-UCD, RRID: MMRRC_036667-UCD). Using the BAC clone RP23-220A13, a Cre-expression cassette was inserted at the initiating ATG codon of the first coding exon of the Rxfp3 gene, enabling Cre expression by the regulatory sequences of the BAC gene. The resulting modified BAC was used to generate the Rxfp3-Cre transgene, allowing expression of Cre recombinase in RXFP3+ cells. Hemizygous male and female RXFP3-Cre mice were paired, and homozygous $\mathrm{Cre}^{+/+}$offspring were used for subsequent breeding. To readily visualise RXFP3+ neurons, homozygous RXFP3-Cre mice were crossed with reporter mice that express either yellow fluorescent protein (YFP) (Rosa26eYFP line; obtained from Dr Toby Merson, Monash University); or tdTomato (Ai14(RCL-tdT)-D. line; Jackson Laboratory, stock number: 007914, RRID: IMSR_JAX:007914) in a Credependent manner to generate RXFP3-Cre/YFP and RXFP3-Cre/tdTomato mice, respectively.

RXFP3-Cre/YFP mice (aged 8 to 12 weeks old) were used for mapping of RXFP3+ neuronal distribution throughout the BNST. We transitioned to the RXFP3-Cre/tdTomato mouse as the tdTomato protein does not require immunoamplification, has stronger endogenous fluorescence, and is more resistant to photobleaching than YFP (Shaner et al., 2004). RXFP3-Cre/tdTomato mice were used for neurochemical phenotyping and electrophysiological recordings. Only male mice were used for electrophysiological recordings, whereas both males and females were used for neurochemical phenotyping to maximise colony usage. Unless stated otherwise, mice were group-housed in a temperature-controlled environment $\left(21-23^{\circ} \mathrm{C}\right)$ and maintained on a 12 hour light/dark cycle (lights on 7 a.m.-7 p.m.) with nesting material and ad libitum access to standard mouse chow (Ridley Agriproducts) and water in their home cage.

\section{$2.2 \quad$ Colchicine treatment}

RXFP3-Cre/YFP mice $(n=3)$ were anaesthetised under isoflurane $(5 \% \mathrm{v} / \mathrm{v}$ in air) in an induction chamber until they lost the righting reflex. Anaesthesia was maintained at $1.5-2 \% \mathrm{v} / \mathrm{v}$ in air. Mice were injected with 
meloxicam (3 mg/kg, i.p.; Boeringher Ingleheim) for perioperative analgesia and mounted into a stereotaxic frame. Depth of anaesthesia was monitored throughout using the paw-withdrawal test. Mice were administered intracerebroventricular (i.c.v.) injections of colchicine (coordinates from bregma: $A / P-0.5 \mathrm{~mm}$, $\mathrm{M} / \mathrm{L} \pm 0.9 \mathrm{~mm}, \mathrm{D} / \mathrm{V}-2.6 \mathrm{~mm})$. Colchicine was dissolved in $0.9 \% \mathrm{NaCl}$ to a final concentration of $10 \mu \mathrm{g} / \mu \mathrm{L}$. A total of $20 \mu \mathrm{g}$ colchicine was infused i.c.v. at a rate of $1 \mu \mathrm{L} / \mathrm{min}$. Mice were transcardially perfused 24 hours later as in section 2.3 and brains were processed for immunohistochemistry (IHC) as described below.

\subsection{Tissue collection and preparation}

Mice were anaesthetised with i.p. injection of sodium pentobarbitone ( $80 \mathrm{mg} / \mathrm{kg}, 0.1 \mathrm{~mL} / \mathrm{mg}$ body weight) and transcardially perfused at a flow rate of $7 \mathrm{~mL} / \mathrm{min}$ for 90 seconds with phosphate buffered saline (PBS $0.1 \mathrm{M}$, $\mathrm{pH}$ 7.4) followed by 6 min of ice-cold 4\% paraformaldehyde (PFA) in 0.1 M PBS. For IHC, brains were post-fixed for an hour in $4 \%$ PFA in $0.1 \mathrm{M}$ PBS at $4^{\circ} \mathrm{C}$ followed by overnight cryoprotection in $20 \%$ sucrose in $0.1 \mathrm{M}$ PBS at $4^{\circ} \mathrm{C}$. Brains were then frozen over dry ice and stored at $-80^{\circ} \mathrm{C}$ until further use. For cryosectioning, brains were mounted in Tissue-Tek Optimal Cutting Temperature compound (Sakura Finetek) and allowed to equilibrate in a cryostat at $-20^{\circ} \mathrm{C}$ for $30 \mathrm{~min}$. Brains were sliced as $40-\mu \mathrm{m}$ coronal sections and floated in microplates filled with $0.1 \%$ sodium azide in $0.1 \mathrm{M}$ PBS. Slices were stored at $4{ }^{\circ} \mathrm{C}$ until further use.

\section{$2.4 \quad$ Immunohistochemistry (IHC)}

To map the distribution of RXFP3+ cells in the BNST, IHC for YFP was performed on every fourth serial brain section through the BNST in RXFP3-Cre/YFP reporter mice. Free-floating sections were removed from cryoprotectant and washed with 0.1 M PBS (3 x 5 min). Sections were pre-blocked with 10\% normal donkey serum (NDS, Millipore), 0.5\% Triton-X 100 (BDH Chemicals) and 0.1 M PBS for 30 min at room temperature. Sections were incubated overnight on a shaker at room temperature with chicken anti-GFP primary antibody (Abcam, 1:1000, RRID: AB_300798) with 2\% NDS and 0.5\% Triton-X 100 in 0.1 M PBS. Sections were washed in $0.1 \mathrm{M}$ PBS ( $3 \times 5 \mathrm{~min})$ and incubated for 2 hours on a shaker in the dark at room temperature with Alexa Fluor 488-conjugated donkey anti-chicken secondary antibody (Invitrogen, 1:200, RRID: AB_2340375) with 0.5\% NDS and $0.5 \%$ Triton X-100. Sections were mounted on slides in $0.1 \mathrm{M} \mathrm{PB}$, coverslipped with DAKO fluorescence mounting medium (Agilent Technologies) and left to dry overnight in the dark. For double or triple-label IHC, free-floating sections from RXFP3-Cre/tdTomato mice were incubated with different primary antibodies (listed 
in Table 1) and corresponding AlexaFluor -conjugated secondary antibodies (listed in Table 2) according to the procedure described above.

\subsection{Antibody characterisation and specificity}

The primary antibodies used in these experiments are all commercially available (Table 1). The chicken antiGFP antibody identifies a single band at 25 kDa in GFP-transfected HEK293 whole cell lysates and elicits positive staining in GFP-transfected NIH3T3 cells but no positive staining in non-GFP-transfected NIH3T3 cells, indicating specificity for GFP (technical information from Abcam). The rabbit anti-GABA antibody (RRID: AB_477652) demonstrates positive binding in a dot blot assay and negative binding with BSA (technical information from Sigma-Aldrich) and has been used extensively for identifying GABAergic neurons in rodent brain (Pérez de Sevilla Müller, Do, Yau, He, \& Baldridge, 2010; Wolansky, Pagliardini, Greer, \& Dickson, 2007). The rabbit anti-vesicular glutamate transporter 2 (VGluT2) antibody (RRID: AB_887883) has been previously verified (Takamori, Rhee, Rosenmund, \& Jahn, 2001). Briefly, this antiserum recognised a single band of $65 \mathrm{kDa}$ in immunoblot using rat brain membrane fraction enriched in synaptic vesicles. Immunoreactive band recognition was completely abolished by preincubation with the antigen used for immunisation. The goat anticalbindin (CB) (RRID: AB_634520) identified a single band at $28 \mathrm{kDa}$ in a Western blot in mouse brain tissue extract (technical information from Santa Cruz). The rabbit anti-calretinin (CR) (RRID: AB_2619710) was verified by preincubation with recombinant human calretinin ( $\mathrm{Xu}$, Roby, \& Callaway, 2010). The mouse antiparvalbumin (PV) (RRID: AB_477329) recognises parvalbumin but not other calcium-binding proteins such as calmodulin, intestinal calcium-binding protein, calcyclin, myosin light chain, or troponin (technical information from Sigma), and immunostaining was eliminated after preadsorption of this antiserum with its antigen (Celio \& Heizmann, 1981). The mouse anti-calcium/calmodulin-dependent protein kinase II (CaMKII) antibody, $\alpha$ subunit, clone 6G9 (RRID: AB_309787) was verified by immunoblot assay in bovine brain cytosol and rat brain microsome samples (technical information from Merck). In addition, this antibody reacts with a single band of $\sim 50 \mathrm{kDa}$ in rat brain homogenates of the hippocampus, cortex, striatum, olfactory bulb, hypothalamus, midbrain, pons/medulla, and cerebellum. This band is removed from homogenates by immunoprecipitation with a different anti-CaMKII antibody (Erondu \& Kennedy, 1985). 
RXFP3-Cre/tdTomato mice ( $n=7$ ) were killed by cervical dislocation and decapitated. Brains were removed and rapidly frozen over isopentane on dry ice. Brains were allowed to freeze for $20 \mathrm{~s}$ and stored at $-80{ }^{\circ} \mathrm{C}$ until further use. For cryosectioning, brains were mounted in Tissue Tek Optimal Cutting Temperature compound (Sakura Finetek) on dry ice. Tissue was allowed to equilibrate to $-17^{\circ} \mathrm{C}$ in the cryostat for $\sim 30$ min. Brains were cryosectioned at $16 \mu \mathrm{m}$ using an anti-roll plate and thaw-mounted onto SuperFrost Plus slides (Thermo Scientific). For fixation, slides were placed in a coplin jar filled with $4 \%$ PFA in 0.1M PBS pre-chilled to $4^{\circ} \mathrm{C}$. Slides were fixed for $15 \mathrm{~min}$ on ice. Slides were washed in $0.1 \mathrm{M}$ PBS ( $2 \times 2 \mathrm{~min})$ and serially dehydrated in $50 \%$ ethanol ( $5 \mathrm{~min}), 70 \%$ ethanol $(5 \mathrm{~min}$ ) and $100 \%$ ethanol $(2 \times 5 \mathrm{~min})$. Slides were placed on absorbent paper and allowed to dry for $5 \mathrm{~min}$ at room temperature. A hydrophobic barrier was drawn around each section with an ImmEdge ${ }^{\mathrm{TM}}$ pen (Vector Laboratories). After allowing the barrier to dry completely ( $\left.\sim \min \right)$, RNAscope ${ }^{\circledR}$ multiplex fluorescent assay was performed as previously described (Gibson et al., 2018). All probes and reagents for the RNAscope ${ }^{\circledR}$ multiplex assay were obtained from Advanced Cell Diagnostics (RNAscope $^{\circledR}$ multiplex fluorescent assay kit, cat. no: ADV320850; Mm-RXFP3 probe, cat. no: ADV439381; TdTomato probe cat. no. ADV317041-C2; Mm-Slc17a6-C2 probe, cat. no: ADV319171-C2).

\subsection{Microscopy and image acquisition}

For visualisation of fluorescent sections, an Olympus BX51 epifluorescence microscope equipped with a Hamamatsu Orca-R2 camera and Stereo Investigator software was used. Photomicrographs were obtained at 10x or 20x magnification with UPlan SApo 10x/0.4 and UPlan SApo 20x/0.95 lenses, respectively. For quantification of double- or triple-labelled cells and visualisation of RNAscope samples, 16-bit z-stacks were obtained with a Zeiss Axio Observer LSM 780 confocal microscope equipped with 488, 594, and 607 diode lasers, and corresponding Zen black software. Photomicrographs were obtained at 20x magnification using a PL-APO 20x/0.8 (DIC) lens. For representative higher power confocal images, photomicrographs were obtained at 63x magnification using a PL-APO 63x/1.4 (DIC) oil lens. The thickness of optical sections was approximately $10 \mu \mathrm{m}$, and z-stacks were acquired in steps of $0.38 \mu \mathrm{m}$. The laser power was set between $5-10 \%$ and gain was set between $500-700$ volts.

\subsection{Slice preparations}

Male RXFP3+ mice were anaesthetised with isoflurane (5\% v/v in air) and killed by cervical dislocation. Brains were quickly removed and placed in ice-cold sucrose-artificial cerebrospinal fluid (aCSF) cutting solution (in 
$\mathrm{mM}$ ): 127 sucrose, $1.9 \mathrm{KCl}, 1.2 \mathrm{KH}_{2} \mathrm{PO}_{4}, 3.9 \mathrm{MgCl}_{2}, 10.0$ glucose, $26.0 \mathrm{NaHCO}_{3}, 0.24 \mathrm{CaCl}_{2}, 0.34$ L-ascorbic acid saturated with $95 \% \mathrm{O}_{2} / 5 \% \mathrm{CO}_{2}, 300 \mathrm{mOsm}$. Multiple $250 \mu \mathrm{m}$ coronal forebrain slices were sectioned (Leica VT1200s) from bregma $0.14 \mathrm{~mm}$ to $-0.34 \mathrm{~mm}$. Slices were transferred to a $4^{\circ} \mathrm{C}$ recording-aCSF (in mM: 127 $\mathrm{NaCl}, 1.9 \mathrm{KCl}, 1.2 \mathrm{KH}_{2} \mathrm{PO}_{4}, 1.3 \mathrm{MgCl}_{2}, 10.0$ glucose, $26.0 \mathrm{NaHCO}_{3}, 2.4 \mathrm{CaCl}_{2}, 0.34 \mathrm{~L}$-ascorbic acid saturated with $\left.95 \% \mathrm{O}_{2} / 5 \% \mathrm{CO}_{2}, 304 \mathrm{mOsm}\right)$ and incubated in a water bath, $\left(32^{\circ} \mathrm{C}, 20 \mathrm{~min}\right)$. The slices remained at room temperature before being transferred to the recording chamber perfused with recording-aCSF $\left(30-32^{\circ} \mathrm{C}, 2\right.$ $\mathrm{mL} / \mathrm{min})$.

\subsection{Whole-cell recordings}

Recording pipettes (3.7-8.7 $\mathrm{M} \Omega$ ) were filled with a low $\mathrm{Cl}^{-}$internal solution (10 $\left.\mathrm{mM} \mathrm{Cl}^{-}\right)$containing (in $\left.\mathrm{mM}\right)$ : $\mathrm{NaCl}, 6 ; \mathrm{NaOH}, 4 ; \mathrm{KOH}$, potassium gluconate, 130; EGTA, 11; $\mathrm{CaCl}_{2}, 1 ; \mathrm{HEPES}, 10 ; \mathrm{MgCl}_{2}, 1 ; 0.4 \%$ biocytin (pH 7.33, $290 \mathrm{mOsmol}$ ). As a consequence, $\mathrm{E}_{\mathrm{Cl}}$ was $-68.8 \mathrm{mV}$ and $\mathrm{Cl}^{-}$currents outward at $\mathrm{V}_{\mathrm{H}}=-40 \mathrm{mV}$. Pipettes were visually guided to BNST neurons using a fixed stage scope (Zeiss Examiner) and camera (Rolera EM-C2, QImaging) where RXFP3+ neurons were identified by tdTomato protein fluorescence. Whole-cell recordings were made in either voltage clamp $\left(\mathrm{V}_{\mathrm{H}}=-60 \mathrm{mV}\right.$ or $-40 \mathrm{mV}$ ) or current clamp mode (MultiClamp $700 \mathrm{~B}$ and pClamp 10.3, Molecular Devices). Signals were sampled at $20 \mathrm{kHz}$ and filtered at $10 \mathrm{kHz}$. Liquid junction potentials were corrected for during analysis $\left(-6.2 \mathrm{mV}\right.$ at $\left.32^{\circ} \mathrm{C}\right)$. Recorded neurons were discarded if leak current exceeded $100 \mathrm{pA}$.

\subsection{Recording protocols and drug application}

We measured the basic electrophysiological characteristics of defined RXFP3+ neurons ( $n=47$ from naive mice, $\mathrm{n}=27$ from stressed mice). This included spontaneous excitatory and inhibitory postsynaptic currents (sEPSCS and SIPSC, respectively) recorded in voltage clamp configuration at $\mathrm{V}_{\mathrm{H}}=-60$ and $40 \mathrm{mV}$, respectively, for $3 \mathrm{~min}$ each. Thereafter, resting membrane potential (RMP) was recorded for 0.5-1 min in current clamp configuration $(I=0 \mathrm{pA})$. Subsequently, two current-voltage protocols were recorded to classify the BNST neuron type as per Hammack, Mania, and Rainnie (2007). Neurons were then subjected to pharmacological manipulations. This included bath application of the selective RXFP3 agonist (RXFP3-A2, $100 \mu$ M) (Shabanpoor et al., 2012), CRF (100-300 nM, Tocris), or the GABA receptor antagonist, GABAzine (SR-95531, 3 mM, Tocris) for 15 min after 3-6 min of baseline recording. To assess independent presynaptic actions of $A 2$ and CRF, these 
were applied in the presence of tetrodotoxin (TTX) $(1 \mu \mathrm{M}$, Tocris Biosciences). At the conclusion of recordings, cell localisation was recorded via photographing the pipette in situ.

\subsection{Synthesis of RXFP3 agonist, A2}

The RXFP3 agonist peptide, A2, was chemically synthesized as reported previously (Shabanpoor et al., 2012). Briefly, we carried out fluorenylmethyloxycarbonyl $(F m o c)$ solid phase assembly of the two chains (A-chain and B-chain) on CEM Liberty ${ }^{\mathrm{TM}}$ microwave peptide synthesizer and then cleavage by trifluoroacetic acid. Both chains had two cysteine residues with one thiol group free and one protected with acetamidomethyl (Acm). The thiol group of the A-chain was activated with a good leaving group (S-pyridinyl; SPyr) and then combined with the purified B-chain. The disulfide bonds were formed regioselectively using thiolysis and iodolysis, respectively (Hossain \& Wade, 2014). The peptides were analysed and purified by reversed phase high performance liquid chromatography (HPLC). The identity of two chains and the final product (A2) was confirmed by matrix-assisted laser-desorption ionization time-of-flight mass spectrometry (MALDI-TOF MS).

\subsection{Data analysis}

For double or triple-labelling IHC experiments, analysis of co-localisation was performed on maximum projection images from confocal stacks of optical sections. Cell quantification was performed manually on digitised photomicrographs using ImageJ software. The percentages of co-labelling were made based on the pooled tdTomato+ cell counts from every fourth serial section through the BNST from 3-5 mice. For RNAscope $^{\circledR}$, a semi-quantitative method was used whereby a DAPI-stained cell was considered positive for RXFP3 and tdTomato or VGluT2 if it contained two or more positively labelled punctae, where each puncta represents a single mRNA molecule (Wang et al., 2012). For RXFP3 and tdTomato co-expression, the numbers of DAPI+/RXFP3+, DAPI+/tdTomato+, and DAPI+/RXFP3+/tdTomato+ cells were quantified manually using the ImageJ cell counter tool. RXFP3 and VGluT2 co-expression was quantified manually in a similar manner. Coexpression analysis was performed on maximum projection images of confocal stacks of optical sections. Only punctae directly apposed to DAPI staining were considered (i.e., if punctae were observed outside of DAPIstained areas, they were not included in quantification). Counts were performed on a representative coronal section at each bregma level containing the BNST according to the Mouse Brain Atlas in Stereotaxic Coordinates (Paxinos \& Franklin, 2004). Data are expressed as mean \pm SEM.

This article is protected by copyright. All rights reserved. 
For determination of RMP, a sample period of at least 30-60 s was averaged (excluding action potentials if present) in Clampfit (Molecular Devices). For analysis of current voltage curves, the response peak and steady state period were made relative to a $50 \mathrm{~ms}$ baseline period before the current steps. The delta membrane potential between the peak and the steady state was calculated to inform neuron classification (Hammack et al., 2007). Spontaneous PSC data, including frequency, amplitude, rise time, decay time, and area (charge transfer) for each event and action potential frequency were analysed in Mini-Analysis (Synaptisoft). For assessment of A2 and CRF effects, a 3 min period of baseline was compared to a 3 min period at the end of 15 min exposure or when the drug impact was maximal.

Data was assessed for normality (D'Agostino-Pearson omnibus and Shapiro-Wilk tests) and a twotailed unpaired t-test was used if the data set was parametric, whereas a Mann-Whitney $U$ test was used for non-parametric data. Drug effects were subjected to a two-tailed paired t-test (parametric) or a Wilcoxon test (non-parametric). For cumulative data sets within neurons, a Kolmogorov-Smirnov test was used. When comparing multiple data sets (e.g., cell types) a two-way ANOVA was employed. Statistical analysis was performed in GraphPad Prism 6. P < 0.05 was considered statistically significant. Individual data points are presented as mean \pm SEM.

\section{Results}

\subsection{Anatomical characterisation of RXFP3-Cre reporter mice}

\subsubsection{RXFP3+ neurons are mainly distributed within the dorsal and posterior BNST}

The distribution of RXFP3+ neuronal elements throughout the BNST was characterised using YFP immunofluorescence as a proxy for RXFP3 expression in RXFP3-Cre/YFP mice $(n=5)$. In general, there was a rostral to caudal gradient of increasing YFP immunofluorescence throughout the BNST (Figure 1), with an enrichment of YFP expression in the posterior subdivisions of the BNST beyond the decussating anterior commissure. The total numbers of YFP+ cells in the BNST at different anatomic levels are shown in Table 3. Rostrally, most YFP expression was contained within the dBNST, with very few YFP+ cell bodies and fibres in the ventral BNST (VBNST). At the anterior-most levels of the BNST, there was a scattering of cells surrounding the anterior commissure at the rostral pole of the BNST (Figure 1a). At the level of the decussating anterior commissure, a scattering of YFP+ neurons was observed within the anteromedial BNST (amBNST), just dorsal to the anterior commissure and lateral to the median preoptic nucleus. YFP immunoreactivity was largely absent from the adjacent oval BNST. More caudally, a population of YFP+ neurons in the amBNST was 
circumscribed medially by the fornix and anterior commissure, and dorsolaterally by the descending fibres of the stria terminalis (Figure 1c). The alBNST encompassing the oval and juxtacapsular nuclei were largely devoid of immunoreactive somata. The posterior BNST (pBNST) contained abundant expression of cell bodies and fibres expressing YFP, especially spanning the medial and intermediate divisions; enclosed medially by the stria medullaris and laterally by the stria terminalis/internal capsule (Figure 1d, e). At caudal levels beyond the decussating commissure, YFP+ neurons filled both dorsal and ventral aspects of the medial BNST. The posterolateral BNST (pIBNST) contained little YFP expression, apart from some YFP+ neuropil-like labelling.

To confirm the veracity of fluorescent protein expression in this reporter mouse, we performed RNAscope ${ }^{\circledR}$ for RXFP3 in RXFP3-Cre/tdTomato mice. We initially attempted to visualise RXFP3 mRNA alongside endogenous tdTomato fluorescence. However, despite several variations of the RNAscope ${ }^{\circledR}$ protocol (including reducing protease treatment time and shortening the length of hybridisation to avoid heat denaturation), we were unable to successfully visualise endogenous tdTomato fluorescence. Therefore, we performed RNAscope ${ }^{\circledR}$ for RXFP3 and tdTomato mRNA at three select levels in the BNST of RXFP3-Cre/tdTomato mice $(n=3)$. The distribution pattern of RXFP3 and tdTomato mRNA throughout the BNST recapitulated that of fluorescent protein in RXFP3-Cre/tdTomato mice, with expression increasing in an anterior to posterior gradient. We analysed the degree of concordance between RXFP3 and tdTomato mRNA co-expression by quantifying the proportion of tdTomato+ cells that co-expressed RXFP3 mRNA at three representative levels in the BNST (rostral, middle, and caudal) (Figure 2a-c). We utilised a semi-quantitative system whereby cells that contained at least two fluorescent punctae were considered positive for that marker. Based on this rubric, $80.5 \%( \pm 1.6 \%)$ of tdTomato+ cells were observed to co-express RXFP3. As a proportion of RXFP3+ cells, $91.1 \%( \pm 3.1 \%)$ coexpressed tdTomato mRNA.

\subsubsection{A subpopulation of BNST RXFP3+ neurons co-express inhibitory markers}

In accordance with previous findings (Cullinan, Herman, \& Watson, 1993; Sun \& Cassell, 1993), a high density of GABA immunoreactive neurons was observed throughout the BNST ( $n=5$ brains examined). Overall, the dBNST contained a higher density of immunolabelled neurons compared to the VBNST, and lateral portions of the BNST were more densely populated than medial portions. The posteromedial BNST (pmBNST) contained a dense population of GABAergic neurons. The percentage of tdTomato+ cells co-expressing GABA was $48 \%$ $( \pm 1 \%)$, suggesting that about half of the BNST RXFP3+ population is inhibitory. 
The calcium-binding proteins calbindin (CB), calretinin (CR), and parvalbumin (PV) are traditionally used as markers of inhibitory interneurons in the neocortex and subpallial regions, and label largely discrete neuronal subpopulations (Celio \& Heizmann, 1981; DeFelipe, 1997; Kawaguchi, 1993). We conducted doublelabelling for these three different calcium-binding proteins and tdTomato ( $n=4$ brains examined). In agreement with previous reports (Nguyen, Dela Cruz, Sun, Holmes, \& Xu, 2016), PV immunoreactivity was negligible, with sparse PV+ cell bodies present throughout the entire BNST. CR immunofluorescence in the dBNST was also sparse. Neither CR nor PV was observed to co-localise with tdTomato. In contrast, widespread CB immunoreactivity was observed throughout the BNST. Within the rostral BNST, a cluster of CB+ neurons was noted in the alBNST. The amBNST and VBNST contained a scattering of CB+ cell bodies. Immediately caudal to the decussating anterior commissure, a high density of CB+ cells was observed in the amBNST, whereas the alBNST contained a more dispersed distribution. CB+ cells were closely packed in the medial division of the pBNST but were more dispersed in its lateral aspects.

We performed triple-labelling for tdTomato, GABA, and CB to simultaneously assess whether a subset of RXFP3+ GABAergic neurons co-expressed CB while also examining co-localisation of CB and GABA ( $n=4$ brains examined). Approximately $25 \%( \pm 4 \%)$ of tdTomato+ cells were observed to co-express CB. Notably, only $45 \%( \pm 3 \%)$ of $\mathrm{CB}+$ cells were also GABA+. In total, $16 \%( \pm 3 \%)$ of tdTomato+ cells showed co-localisation with both GABA and $C B$, suggesting that a subpopulation of RXFP3+ neurons are both GABA+ and CB+ (Figure 3a-d). Table 4 summarises the relative proportions of RXFP3 cells that co-localise with either GABA and/or CB. Taken together, GABA and/or CB accounted for approximately $60 \%$ of RXFP3+ neurons.

\subsubsection{A subset of BNST RXFP3+ neurons co-express excitatory markers}

CaMKIl $\alpha$ is a well-established marker of excitatory neurons (Benson, Isackson, Hendry, \& Jones, 1991). CaMKIl $\alpha$ immunostaining was abundant in the dBNST, with the majority of CaMKIl $\alpha+$ cells clustered within the oval and juxtacapsular BNST. The amBNST contained a scattered distribution of CaMKIl $\alpha+$ cells. In the pBNST, a strip of CaMKIl $\alpha+$ cells filled the medial division adjacent to the stria medullaris, whereas CaMKII $\alpha$ IR was more dispersed in the lateral division. The vBNST contained a few scattered CaMKIl $\alpha+$ cells along the ventral border of the anterior commissure. Quantification of tdTomato+/CaMKIl $\alpha+$ double-labelled cells revealed that $41 \%$ $( \pm 5 \%)$ of tdTomato+ neurons co-expressed CaMKIl $\alpha$ (Figure 3e-g). To examine if BNST RXFP3+ neurons were glutamatergic, we conducted IHC for VGluT2 and YFP in colchicine-treated RXFP3-Cre/YFP mice. VGluT2 immunostaining was evident throughout the BNST. Immunolabelled elements corresponded mainly to punctae surrounding cell bodies but did not clearly label neuronal perikarya despite colchicine treatment.

This article is protected by copyright. All rights reserved. 
Because of the difficulty in visualising VGluT2 IR in somata, RNAscope was employed with custom probes for mouse RXFP3 and VGluT2 mRNA. The distribution of RXFP3 mRNA in the BNST recapitulated the pattern of YFP and tdTomato expression with a rostral to caudal gradient of increasing density and demarcated expression in the medial portions of the BNST. Notably, RXFP3 mRNA was detected in the vBNST at rostral levels, whereas comparatively few immunopositive cells were observed in this region. In accordance with previous reports in rodent (Hur \& Zaborsky, 2005; Kudo et al., 2012; Poulin, Arbour, Laforest, \& Drolet, 2009), VGluT2 mRNA expression was observed throughout the rostrocaudal extent of the BNST, in both dorsal and ventral portions. A prominent cluster of VGluT2+ cells was noted skirting the dorsal edge of the anterior commissure just after its decussation. In many cells, discrete punctae were clearly visible. Each puncta is believed to represent an individual mRNA molecule (Player, Shen, Kenny, Antao, \& Kolberg, 2001; Wang et al., 2012). No signal was detected in the negative control (data not shown). We utilised a semi-quantitative system to quantify the proportion of RXFP3+/VGluT2+ cells, whereby cells that contained at least two fluorescent punctae were considered positive for that marker. Using this scoring, it was determined that $35 \%( \pm 1 \%)$ of RXFP3+ cells co-expressed VGluT2, suggesting that about $1 / 3$ of RXFP3+ neurons are glutamatergic. As a proportion of BNST glutamatergic cells, $29 \%$ ( $\pm 3 \%$ ) of VGluT2+ cells co-localised with RXFP3 mRNA (Figure 3h).

\subsection{Electrophysiological characterisation of BNST RXFP3+ neurons}

\subsubsection{BNST RXFP3+ neurons are predominantly Type II neurons}

BNST RXFP3+ neurons were identified by tdTomato immunofluorescence and targeted for whole cell recordings (Figure 4a). They exhibited a resting membrane potential of $-58 \pm 1 \mathrm{mV}$ ( $\mathrm{n}=47$ from naive mice). To determine the similarity of BNST RXFP3+ neurons to other populations of BNST neurons, we classified them based on their membrane voltage responses to both current injection and subtraction steps (Figure 4). These depend on the differential expression of voltage-activated ion channels and have been characterised previously (Hammack et al., 2007). We found $>75 \%$ of BNST RXFP3+ neurons exhibited a depolarising sag and spikes were triggered when the rectification surpassed the action potential threshold (Figure $4 \mathrm{~b}$ ) and were therefore classified as Type II (Figure 4c). The next major cohort ( $>15 \%$ ) exhibited an $I_{h}$ current but no rebound depolarization and were classified as Type I. A single neuron exhibited currents attributed to $I_{K(I R)}$ and was classified as Type III. Of the 30 neurons assayed in this way (naive mice), 29 conformed to the previously published parameters. One neuron type exhibited both inward rectification and rebound spikes in response to the hyperpolarization steps that differentiated it from neuron Types I-III which we have designated "other" (Figure $4 \mathrm{~b}, \mathrm{c}$ ). With the exception of Type I neurons tending to be located in the caudal BNST, there was no obvious differential localisation between different cell types (Figure $3 \mathrm{~d}$ ).

This article is protected by copyright. All rights reserved. 
IHC demonstrated VGluT2 immunoreactivity in punctae closely apposed to dBNST RXFP3+ neurons (Figure 5a), suggesting that they receive dense glutamatergic input. Whole cell recordings in voltage clamp configuration were taken to assess excitatory and inhibitory input to dBNST RXFP3+ cells. Nearly all BNST RXFP3+ neurons exhibited sEPSCs (Figure 5b, red) and sIPSCs (Figure 5c, blue). Within neurons, excitatory and inhibitory spontaneous input was essentially balanced in terms of frequency and amplitude.

\subsubsection{RXFP3 activation hyperpolarizes BNST RXFP3+ neurons}

To determine the impact of RXFP3 activation in BNST neurons, we bath applied the selective RXFP3 agonist A2 (100 nM) (Shabanpoor et al., 2012). A2 evoked hyperpolarized RXFP3+ neurons to suppress spontaneous action potential firing, which reversed on washout (Figure 6a). To isolate this action from potential presynaptic factors, we repeated this experiment in the presence of TTX. Under these conditions, A2 still hyperpolarised RXFP3+ neurons (Figure 6b) indicating that these effects were mediated by postsynaptic actions of RXFP3. Across neurons, we observed the majority of neurons were hyperpolarised by A2 application (-61.4 $\pm 1.9 \mathrm{mV}$ in aCSF to $-66.0 \pm 2.7 \mathrm{mV}$ in $A 2, n=9$ ). In the presence of TTX, A2 significantly hyperpolarized BNST RXFP3+ neurons (-58.6 $\pm 2.1 \mathrm{mV}$ in aCSF and TTX to $-61.0 \pm 1.6 \mathrm{mV}$ in $\mathrm{A} 2$ and TTX, $n=9, p<0.05$, paired t-test. Figure $6 \mathrm{c})$.

In addition to direct postsynaptic effects, the RXFP3 agonist A2 differentially modulated presynaptic input across BNST RXFP3+ neurons (Figure 7). In some neurons, A2 decreased the frequency of sIPSCs without impacting sIPSC amplitude (Figure 7a). In others, A2 increased the frequency and amplitude of sIPSCs. In all cases tested $(n=5)$, sIPSCs were completely blocked by the $\mathrm{GABA}_{A}$ receptor antagonist, gabazine (GBZ, Figure 7b). Despite clear, reversible impacts on GABA release within individual neurons, we observed that variability across the group was high. Consequently, no statistical significance was noted (Figure 7d). A2 also impacted spontaneous glutamate release onto dBNST RXFP3+ neurons. Similar to sIPSCs, the result was either a decrease or increase in the frequency of events that in each case was reversed with washout (Figure 7c). Similarly, variability was high across the group, and no statistical significance was noted (Figure 7e).

\subsubsection{BNST RXFP3+ neurons are responsive to CRF and exhibit stress-induced plasticity}

To investigate the role of BNST RXFP3+ neurons in stress-related behaviours, we assessed if BNST RXFP3+ neurons also express CRF. Based on IHC, RXFP3+ neurons did not appear to co-localise with CRF-containing neurons. However, immunostaining provided evidence of putative CRF input onto dBNST RXFP3+ cells (Figure 8a). To test this functionally, we bath applied exogenous CRF (100-300 nM) that depolarized membrane potential and initiated or increased the frequency of action potential firing in some BNST RXFP3+ neurons (, Figure $8 b$ ). Across the cohort $(n=11)$, over half (6 of 11 neurons) the dBNST RXFP3+ cells depolarized in response to CRF where resting membrane potential increased to $-55.6 \pm 3$ from $-59.8 \pm 2.7(n=6)$ and in two 
cells CRF increased their firing rate from $0.6 \pm 0.5$ to $1.6 \pm 1 \mathrm{~Hz}$ but no other neurons reached threshold (Figure $8 c)$.

Based on this modulation by CRF, we hypothesised that dBNST RXFP3+ neurons would be sensitive to stress. To examine this possibility, we subjected mice to $6 \mathrm{~min}$ of swim stress daily for 5 consecutive days. Twenty-four hours after the final stressor, we obtained brain slices for electrophysiological recordings (Figure 9a). We repeated every protocol to that performed in naïve slices, and present the two major changes we observed here (Figure 9). Strikingly, chronic swim stress reduced the proportion of Type II neurons, while Type III and 'other' neurons increased their representation (Figure 9b). However, this change in cell type ratio did not alter the resting membrane potential of RXFP3+ neurons with chronic stress exposure (Figure 9c). The location of recorded RXFP3+ neurons within the BNST between naïve and stress cohorts was similar (Figure 9d). There was no difference in the ratio of SEPSCs and SIPSCs in individual cells between naïve and swim stress mice (Figure 8e). In addition to the changes in voltage-gated ion channel expression, we recorded an increase in the decay time of sIPSCs within the stress cohort neurons as compared to naive controls (Figure 9f). A twoway ANOVA revealed a main effect of stress $[F(1,39)=10.98, p=0.002]$, but no stress $x$ cell type interaction (Figure 9g). We then tested if stress altered $A 2$ and CRF responses. We found no difference in how $A 2$ altered sIPSC and SEPSC frequency (Figures $9 \mathrm{~h}$ and $9 \mathrm{i}$ ) between the cohorts. Similarly, chronic stress did not alter the proportion or magnitude or variability of A2-evoked hyperpolarization $(n=8)$ or CRF-evoked depolarization $(n=$ 5) in RXFP3+ neurons (Figure 9j).

\section{Discussion}

This series of studies is the first to systematically characterize the distribution, neurochemical phenotype, and electrophysiological characteristics of BNST RXFP3+ neurons in mice. A main finding that emerged is that BNST RXFP3+ neurons are neurochemically and electrophysiologically heterogeneous, and show persistent adaptation following stress.

\subsection{Distribution of RXFP3+ neurons in the BNST}

RXFP3-Cre/YFP mice were employed to assess the distribution of RXFP3+ neurons in mouse BNST using YFP as a surrogate for RXFP3 expression. The density of YFP expression increased in a rostral to caudal gradient throughout the BNST. Most YFP expression was concentrated within the dorsomedial and caudal portions of the BNST. This pattern of YFP distribution largely agrees with our in situ hybridisation studies. In this regard, to 
confirm whether Cre-driven reporter expression faithfully recapitulates RXFP3 expression in this transgenic mouse, we performed RNAscope ${ }^{\circledR}$ for $R X F P 3$ and tdTomato mRNA at three representative levels in the BNST. The majority of tdTomato+ cells $(>80 \%)$ co-expressed RXFP3 message. This high degree of co-expression implies that the vast majority of cells expressing fluorescent reporter protein do indeed express RXFP3. Indeed, analyzed by RXFP3 mRNA expression, over $90 \%$ of these cells also expressed tdTomato. These anatomical correlates lend credence to the fidelity of the RXFP3-Cre reporter mouse as a useful tool to study the RXFP3 system. However, there were instances where YFP expression did not show complete concordance with RXFP3 mRNA expression. For instance, a scattering of YFP+ cells was observed surrounding the rostral cap of the anterior commissure in the dBNST, but no RXFP3 mRNA seems to be recorded in this region based on our RNAscope ${ }^{\circledR}$ results. This could be due to the more transient and dynamic nature of mRNA expression relative to protein expression. Indeed, an important caveat to using transgenic mouse lines is that the fluorescent protein readily fills somata, dendrites, and axons of neurons, thus providing a qualitative marker of cells in which the gene of interest is actively promoted. Nevertheless, discordance between the turnover or ultrastructural distribution of receptor and fluorescent protein due to differential regulation of the receptor at the post-transcriptional or translational level could contribute to either over- or underestimating actual receptor content. Thus, although the presence of functional receptor cannot be concluded based on expression profiles of fluorescent protein alone, it does indicate that those cells did actively express the receptor at some point. In our electrophysiological recordings, most recorded tdTomato+ cells responded to the RXFP3 agonist A2, indicating that reporter-positive cells do indeed express functional RXFP3 and lending further support to the fidelity of Cre expression in this reporter mouse.

Based on cytoarchitectural, chemoarchitectural, and connectional similarities, the classical parcellation scheme for the extended amygdala considers the medial BNST as an anatomic continuum of the medial amygdala (MeA), and the lateral BNST an extension of the lateral central amygdala (CeL) (de Olmos \& Heimer, 1999; Paxinos \& Watson, 1986). Throughout the rostrocaudal axis, YFP+ neurons were largely confined to the medial portions of the BNST, with limited expression in the lateral BNST. Based on the Allen Brain Atlas (http://mouse.brain-map.org/), RXFP3 mRNA in the mouse brain appears to be circumscribed to the MeA and medial central amygdala (CeM), with minimal expression in the adjacent regions of the CeA. These observations reinforce the notion that the BNST and amygdala can be classified into medial-lateral subdivisions that are neurochemically similar, and support the concept of an extended amygdala macrostructure. In addition, a high density of YFP+ neurons was observed throughout the posteromedial (pmBNST). The pmBNST is strongly connected with the accessory olfactory system, MeA, and medial preoptic area (MPO). These loci are critical nodes within the social behaviour neural network (Newman, 1999), 
suggesting that the BNST RXFP3+ system may be involved in social and/or reproductive behaviour in addition to its role in stress-induced reward-seeking.

\subsection{Inhibitory markers in BNST RXFP3+ neurons}

Concordant with previous findings in rodents (Cullinan et al., 1993; La Salle, Paxinos, Emson, \& Ben-Ari, 1978; Sun \& Cassell, 1993), cats (Paré \& Smith, 1993), and primates (Benson et al., 1991), we observed a high density of GABAergic cells in the BNST of RXFP3-Cre reporter mice. Approximately half (48\%) of RXFP3+ cells were GABAergic. Morphologically, GABAergic cells in the rodent BNST are mostly classified as medium spiny neurons (MSNs) (McDonald, 1983). MSNs possess large dendritic arborisations that receive widespread input and extensive axon collaterals that offer dense local innervation to other MSNs (Preston, Bishop, \& Kitai, 1980). This architecture permits integration of multiple modality information and signal processing within the BNST. At a behavioural level, GABAergic signalling in the BNST is involved in regulating anxiety. For instance, chronic inhibition of GABA synthesis in the BNST promoted anxiogenic behaviours in rats (Sajdyk, Johnson, Fitz, \& Shekhar, 2008). Further, GAD65 mRNA levels were increased in the pmBNST of young and middle-aged rats following chronic stress, although the opposite effect was observed in aged rats, suggesting that the molecular signature of the pmBNST following prolonged stress can change with age (Herman \& Larson, 2001).

We also assessed the calcium-binding proteins PV, CR, and CB for co-localisation with tdTomato. These calcium-binding proteins have traditionally been considered markers of discrete populations of inhibitory interneurons in cortical and subpallial regions (Celio \& Heizmann, 1981; DeFelipe, 1997; Hendry et al., 1989; Kawaguchi, 1993). CB immunoreactivity was abundant throughout the BNST, with an enrichment of cells in medial portions of the BNST in accordance with previous studies in mice (Frantz \& Tobin, 1994). Prominent CB expression has also been noted in the medial BNST of hamsters (Duncan \& Franklin, 2007), rats (Kemppainen \& Pitkanen, 2000; Sequier, Hunziker, Andressen, \& Celio, 1990), primates (Côté, Sadikot, \& Parent, 1991; Fudge \& Tucker, 2009), and humans (Walter, Mai, Lanta, \& Görcs, 1991), suggesting conservation of CB expression in the BNST across multiple species. Approximately $25 \%$ of RXFP3+ neurons colocalised with $C B$, and $16 \%$ of RXFP3+ cells were both GABA+/CB+. However, no co-localisation of PV or CR in RXFP3+ cells was detected. The paucity of PV immunolabelling in the BNST is in line with previous studies (Nguyen et al., 2016).

Notably, only $45 \%$ of $C B+$ neurons were observed to co-express GABA. This suggests that a portion of $\mathrm{CB}+$ cells may use a different inhibitory transmitter, such as glycine. Indeed, $\mathrm{CB}$ and glycine are highly colocalised in rat vestibular ganglion cells (Bäurle, Kleine, Grüsser, \& Guldin, 1997), and CB is more frequently coexpressed with glycine than GABA in Renshaw cells (Geiman, Zheng, Fritschy, \& Alvarez, 2002). Another 
potential explanation is that CB may not necessarily be restricted to inhibitory neurons. Some excitatory CA1 pyramidal cells and dentate granule cells in the hippocampus (Lowenstein, Miles, Hatam, \& McCabe, 1991) and a small proportion of glutamatergic cells in the basolateral amygdala (Dávila et al., 2008) have been reported to express $\mathrm{CB}$.

\subsection{Excitatory markers in BNST RXFP3+ neurons}

CaMKII $\alpha$ is a protein kinase critical for long-term potentiation and synaptic plasticity (Silva, Stevens, Tonegawa, \& Wang, 1992). With the exception of cerebellar Purkinje cells and the commissural nucleus, CaMKIl $\alpha$ does not co-localise with glutamic acid decarboxylase (GAD) in the rodent brain, implying that CaMKII $\alpha$ is predominantly expressed in non-GABAergic neurons and is recognised as a marker for excitatory neurons (Benson et al., 1991; McDonald, Muller, \& Mascagni, 2002). We noted strong CaMKIl $\alpha$ IR in the alBNST and to a lesser extent in the pBNST, in line with previous reports in rats (Erondu \& Kennedy, 1985) and mice (Nguyen et al., 2016; Olsen et al., 2008).

CaMKIl $\alpha$ was expressed in $41 \%$ of tdTomato+ cells, suggesting that just under half of the BNST RXFP3+ population is excitatory. To corroborate this, we conducted RNAscope to investigate co-expression of VGluT2 and RXFP3 mRNA in BNST cells. The sensitivity of RNAscope allows detection of single mRNA transcripts within their preserved morphological context (Wang et al., 2012). In total, 35\% of BNST RXFP3+ cells appeared to co-express VGluT2; this percentage falls within $\sim 5 \%$ of the percentage of CaMKIl $\alpha+$ /tdTomato+ neurons. The slightly higher percentage of RXFP3+ neurons expressing CaMKIl $\alpha$ compared to VGluT2 suggests that some excitatory RXFP3+ neurons may express VGluT3. Of note, we documented RXFP3 mRNA at anterior levels of the vBNST, although YFP and/or tdTomato immunoreactivity was sparse in these regions. This discrepancy could be due to several factors. For instance, not all mRNA is translated into functional protein due to posttranscriptional regulation, and the relative abundance of mRNA in cells may differ from protein levels.

Furthermore, RNAscope ${ }^{\oplus}$ has higher sensitivity than immunohistochemical detection with antibodies. Indeed, a distinguishing feature of RNAscope is its exquisite sensitivity. This is afforded by sequential binding of amplifier molecules to the preamplifier, permitting signal amplification in a multiplicative manner (Cassidy \& Jones, 2014). This iterative process allows detection of low abundance mRNA molecules, including transcripts for GPCRs (such as RXFP3), which are encoded by scarce mRNAs and often fully functional at levels less than $1 \times 10^{4}$ molecules per cell (Ostrom \& Insel, 2004).

\subsection{Electrophysiological characteristics and stress-induced plasticity of BNST RXFP3+ neurons}


In previous studies, a selective RXFP3 agonist, R3/I5, modulated the excitability of undefined rat intergeniculate leaflet neurons (Blasiak et al., 2013). R3/I5 hyperpolarized 67\% of responsive neurons while the remainder were depolarized (van der Westhuizen et al., 2007). The selective RXFP3 agonist, A2, also predominantly induced a Gai/o-protein-dependent hyperpolarization in 70\% of neurons in the paraventricular nucleus (Kania et al., 2017). In the mouse BNST, the majority of RXFP3+ neurons were hyperpolarized by A2, an effect preserved in the presence of TTX. RXFP3 predominantly couples to Gai/o (Bathgate et al., 2013), and RXFP3 activation via this second messenger is calcium-dependent (Kania et al., 2017). Cells unaffected by the RXFP3 agonist may indicate a lack of functional RXFP3 expression in their cell membranes at the time of recording. Moreover, our RNAscope ${ }^{\circledR}$ analysis demonstrated that just over $80 \%$ of tdTomato+ cells also expressed RXFP3 mRNA; therefore one might not expect every reporter-positive cell to respond to bathapplied agonist. Notably, we observed no difference in the magnitude or proportion of RXFP3+ neurons hyperpolarized in response to A2 between naïve and stress groups. Indeed, functional outcomes may not always be reflective of the degree of reporter expression in neurons. For example, only $38 \%$ of leptin receptorYFP neurons depolarize in response to bath-applied leptin (Simonds et al., 2014).

Hammack and colleagues established electrophysiological classification criteria for neurons in the rat alBNST (Hammack et al., 2007). This concept is now widely used to similarly classify neurons in other subnuclei of the BNST in rats, mice, and primates (Daniel, Guo, \& Rainnie, 2017; Rodríguez-Sierra, Turesson, \& Pare, 2013; Silberman et al., 2013). These neuronal types are differentiated by the presence of distinct ionic currents $\left(I_{h}, I_{T}, I_{K(\mathbb{R})}, I_{A}\right)$. Type I RXFP3+ neurons exhibited a time- and voltage-dependent depolarizing sag, corresponding to the non-selective cation current, $I_{h}$ (Robinson \& Siegelbaum, 2003). Type II RXFP3+ neurons displayed both the sag and a T-type calcium channel-mediated enhanced rebound depolarization; spikes $\left(I_{T}\right)$ were usually triggered as well (Randall \& Tsien, 1997). A time-independent depolarizing rectification potassium current $\left(I_{K(\mathbb{R})}\right)$ identified Type III RXFP3+ neurons (Nichols \& Lopatin, 1997). Within the population of RXFP3+ neurons in the mouse BNST, over $75 \%$ were Type II, while $50 \%$ of all neurons in the rat dBNST are Type II (RodriguezSierra, Turesson, \& Pare, 2013). Besides the established neuron types (I-III), we observed a new neuron type, which we have termed "other", that exhibited consistent responses to current manipulations in both naïve and stress groups. The presence of both inward rectification and rebound spikes in response to hyperpolarization currents made the "other" neurons distinguishable from Types I-III. This is not the first instance that BNST neurons have not fallen into the established response categories. For example, 13 of 23 recorded BNST CRF+ neurons do not fit into the classic criteria (Silberman et al., 2013). Here, all "other" neurons exhibited the same response patterns, suggesting that they express a similar channel profile. 
BNST Type II neurons may modulate the activity of local Type III VTA-projecting neurons, thereby modulating stress-relevant information (Nagano et al., 2015). Hammack and colleagues have postulated that Type II alBNST neurons are predominantly spiny neurons which have short axons and therefore may modulate the activity of local networks (Hammack et al., 2007; Larriva-Sahd, 2006). This raises the possibility that Type II RXFP3+ neurons are local interneurons that modulate BNST projection neurons. As over $50 \%$ of the BNST RXFP3+ neurons are GABAergic, it is likely that at least some of the Type II RXFP3+ neurons are inhibitory interneurons. Hammack proposed that BNST Type II neurons shift from tonic to burst firing activity in response to environmental changes, which favors greater neuropeptide release, thereby modulating output neurons differently (Hammack et al., 2007). This may also be the case for Type II RXFP3+ neurons, thus enabling them to integrate stress responses.

Chronic stress exposure altered the proportion of defined neuronal types, such that Type III and Type II RXFP3+ neurons increased and decreased, respectively. This transition reflects a change in voltage-activated ion channel expression and, consequently, neuronal function. In this regard, chronic stress may induce a transition from $I_{T}$ current to $I_{K(\mathbb{R})}$ and $I_{A}$-mediated currents in these cells. mRNA expression profiling demonstrates a high level of Kir2.2 and Kir2.3 mRNA within Type III neurons in the rat alBNST (Hazra et al., 2011), in which these Kir ion channels commonly exist in somata and dendrites (Inanobe et al., 2002; Pruss, Derst, Lommel, \& Veh, 2005), where they maintain and regulate membrane potential (Chevaleyre \& Castillo, 2002; Hibino et al., 2010; Nichols \& Lopatin, 1997). Considering the electrophysiological similarity between Type III RXFP3+ neurons and Type III alBNST neurons, we propose that Type III RXFP3+ neurons express Kir2 family subunits. Note, however, that resting membrane potential was not altered by stress. Chronic swim stress increased the decay time of sIPSCs but did not change the amplitude of these events. The outward IPSCS were $\mathrm{GABA}_{\mathrm{A}}$ receptor-mediated, as they were abolished by gabazine (SR-95531). This suggests that the longer decay time for sIPSCs in RXFP3+ neurons after stress is due to an altered composition of $\mathrm{GABA}_{\mathrm{A}}$ receptor subunits compared to that of naive mice. Different $G_{A B A}$ subunit composition underlies receptor function (Dixon, Sah, Lynch, \& Keramidas, 2014). In the hippocampus, mRNA for $\mathrm{GABA}_{\mathrm{A}}$ receptor subunits was decreased following a 14-day swim stress protocol (Montpied et al., 1993). Considering the RXFP3+ neuronal population as a whole, we suggest that the combined transition from the type II category and increased temporal inhibition with GABA input renders these neurons more tuned to chronic stress.

Across the population of BNST RXFP3+ neurons, we observed plasticity in ion channel expression with chronic swim stress without any persistent indications of change in presynaptic function. These postsynaptic changes suggest that RXFP3+ neurons are involved in stress responses within the BNST. In this regard, we also observed that exogenous application of CRF increased the membrane potential and frequency of action 
potentials in approximately half of the BNST RXFP3+ neurons assayed. These data matched the evidence from immunostaining of putative CRF contacts onto BNST RXFP3+ neurons. CRF and its receptors, CRFR1 and CRFR2, are expressed in BNST neurons in rat and mouse. In both species, CRFR1 mRNA is more abundant in the BNST (van Pett et al., 2000). The origin of CRF afferents to RXFP3+ neurons may include local BNST CRF+ neurons or projections from the central nucleus of the amygdala (Pomrenze et al., 2015). Thus, BNST RXFP3+ cells may be implicated in stress circuitry via CRF afferent activity. Indeed, at a systems level, stress-induced release of endogenous CRF may activate relaxin-3 neurons within the nucleus incertus (Ma, Blasiak, Olucha-Bordonau, Verberne, \& Gundlach, 2013; Walker, Kastman, Koeleman, et al., 2017) to precipitate relapse to alcoholseeking via activation of upstream RXFP3+ neurons within the BNST (Ryan et al., 2013) and central amygdala (Walker, Kastman, Krstew, Gundlach, \& Lawrence, 2017).

\subsection{Conclusion}

To conclude, we have characterised the neurotransmitter content of BNST RXFP3+ neurons in the mouse brain and established that BNST RXFP3+ neurons are directly hyperpolarized by a selective RXFP3 agonist. Furthermore, a subpopulation of BNST RXFP3+ cells receives putative CRF input and shows plastic adaptation following chronic swim stress. These findings concur with the established role of RXFP3 signalling within the BNST in stress-related relapse to alcohol-seeking (Ryan et al., 2013). Collectively, these experiments lay the foundation for using the RXFP3-Cre reporter mouse to examine the functional involvement of relaxin3/RXFP3 signalling in the BNST in complex behaviours. 


\section{References:}

Alheid, G. F. (2003). Extended amygdala and basal forebrain. Annals of the New York Academy of Sciences, 985, 185-205.

Aston-Jones, G., \& Harris, G. C. (2004). Brain substrates for increased drug seeking during protracted withdrawal. Neuropharmacology, 47(1), 167-179.

Bathgate, R., Halls, M., Van Der Westhuizen, E., Callander, G., Kocan, M., \& Summers, R. (2013). Relaxin family peptides and their receptors. Physiological Reviews, 93(1), 405-480.

Bathgate, R. A. D., Samuel, C. S., Burazin, T. C. D., Layfield, S., Claasz, A. A., Reytomas, I. G., . . Tregear, G. W. (2002). Human relaxin gene 3 (H3) and the equivalent mouse relaxin (M3) gene. Novel members of the relaxin peptide family. Journal of Biological Chemistry, 277(2), 1148-1157.

Bäurle, J., Kleine, J., Grüsser, O., \& Guldin, W. (1997). Co-localization of glycine and calbindin D-28k in the vestibular ganglion of the rat. Neuroreport, 8(11), 2443-2447.

Benson, D. L., Isackson, P. J., Hendry, S. H. C., \& Jones, E. G. (1991). Differential gene expression for glutamic acid decarboxylase and type II calcium-calmodulin-dependent protein kinase in basal ganglia, thalamus, and hypothalamus of monkey. Journal of Neuroscience, 11(6), 1540-1564.

Blasiak, A., Blasiak, T., Lewandowski, M. H., Hossain, M. A., Wade, J. D., \& Gundlach, A. L. (2013). Relaxin-3 innervation of the intergeniculate leaflet of the rat thalamus-neuronal tract-tracing and in vitro electrophysiological studies. European Journal of Neuroscience, 37(8), 1284-1294.

Briand, L. A., Vassoler, F. M., Pierce, R. C., Valentino, R. J., \& Blendy, J. A. (2010). Ventral tegmental afferents in stress-induced reinstatement: the role of cAMP response element-binding protein. Journal of Neuroscience, 30(48), 16149-16159.

Buffalari, D. M., \& See, R. E. (2011). Inactivation of the bed nucleus of the stria terminalis in an animal model of relapse: effects on conditioned cue-induced reinstatement and its enhancement by yohimbine. Psychopharmacology (Berl), 213(1), 19-27.

Cassidy, A., \& Jones, J. (2014). Developments in in situ hybridisation. Methods, 70(1), 39-45.

Celio, M., \& Heizmann, C. (1981). Calcium-binding protein parvalbumin as a neuronal marker. Nature, 293(5830), 300-302.

Ch'ng, S., Fu, J., Brown, R. M., McDougall, S. J., \& Lawrence, A. J. (2018). The intersection of stress and reward: BNST modulation of aversive and appetitive states. Progress in Neuro-Psychopharmacology and Biological Psychiatry, 87, 108-125.

Chevaleyre, V., \& Castillo, P. E. (2002). Assessing the role of Ih channels in synaptic transmission and mossy fiber LTP. Proceedings of the National Academy of Sciences, 99(14), 9538-9543. 
Côté, P. Y., Sadikot, A. F., \& Parent, A. (1991). Complementary distribution of calbindin D-28k and parvalbumin in the basal forebrain and midbrain of the squirrel monkey. European Journal of Neuroscience, 3(12), 1316-1329.

Cullinan, W. E., Herman, J. P., \& Watson, S. J. (1993). Ventral subicular interaction with the hypothalamic paraventricular nucleus: evidence for a relay in the bed nucleus of the stria terminalis. Journal of Comparative Neurology, 332, 1-20.

Daniel, S. E., Guo, J., \& Rainnie, D. G. (2017). A comparative analysis of the physiological properties of neurons in the anterolateral bed nucleus of the stria terminalis in the Mus musculus, Rattus norvegicus, and Macaca mulatta. Journal of Comparative Neurology, 525(9), 2235-2248.

Dávila, J., Olmos, L., Legaz, I., Medina, L., Guirado, S., \& Real, M. (2008). Dynamic patterns of colocalization of calbindin, parvalbumin and GABA in subpopulations of mouse basolateral amygdalar cells during development. Journal of Chemical Neuroanatomy, 35, 67-76.

de Olmos, J. S., \& Heimer, L. (1999). The concepts of the ventral striatopallidal system and extended amygdala. Annals of the New York Academy of Sciences, 877, 1-32.

Defelipe, J. (1997). Types of neurons, synaptic connections and chemical characteristics of cells immunoreactive for calbindin-D28K, parvalbumin and calretinin in the neocortex. Journal of Chemical Neuroanatomy, 14, 1-39.

Di Bonaventura, M. V. M., Ciccocioppo, R., Romano, A., Bossert, J. M., Rice, K. C., Ubaldi, M., . . Cifani, C. (2014). Role of the bed nucleus of the stria terminalis corticotrophin-releasing factor receptors in frustration stress-induced binge-like palatable food consumption in female rats with a history of food restriction. Journal of Neuroscience, 34(34), 11316-11324.

Dixon, C., Sah, P., Lynch, J. W., \& Keramidas, A. (2014). GABAA receptor $\alpha$-and $\gamma$-subunits shape synaptic currents via different mechanisms. Journal of Biological Chemistry, 289, 5399-5411.

Dong, H. W., \& Swanson, L. W. (2004). Organization of axonal projections from the anterolateral area of the bed nuclei of the stria terminalis. Journal of Comparative Neurology, 468(2), 277-298.

Dong, H. W., \& Swanson, L. W. (2006). Projections from bed nuclei of the stria terminalis, anteromedial area: cerebral hemisphere integration of neuroendocrine, autonomic, and behavioral aspects of energy balance. Journal of Comparative Neurology, 494(1), 142-178.

Dumont, E. C., Mark, G. P., Mader, S., \& Williams, J. T. (2005). Self-administration enhances excitatory synaptic transmission in the bed nucleus of the stria terminalis. Nature Neuroscience, 8(4), 413-414.

Duncan, M. J., \& Franklin, K. M. (2007). Expression of 5-HT7 receptor mRNA in the hamster brain: Effect of aging and association with calbindin-D28K expression. Brain Research, 1143, 70-77.

This article is protected by copyright. All rights reserved. 
Erb, S., Salmaso, N., Rodaros, D., \& Stewart, J. (2001). A role for the CRF-containing pathway from central nucleus of the amygdala to bed nucleus of the stria terminalis in the stress-induced reinstatement of cocaine seeking in rats. Psychopharmacology (Berl), 158, 360-365.

Erb, S., \& Stewart, J. (1999). A role for the bed nucleus of the stria terminalis, but not the amygdala in the effects of corticotropin-releasing factor in stress-induced reinstatement of cocaine seeking. Journal of Neuroscience, 19, 1-6.

Erondu, N. E., \& Kennedy, M. B. (1985). Regional distribution of type II Ca2+/calmodulin-dependent protein kinase in rat brain. Journal of Neuroscience, 5(12), 3270-3277.

Frantz, G. D., \& Tobin, A. J. (1994). Cellular distribution of calbindin D28K mRNAs in the adult mouse brain. Journal of Neuroscience Research, 37, 287-302.

Fudge, J. L., \& Tucker, T. (2009). Amygdala projections to central amygdaloid nucleus subdivisions and transition zones in the primate. Neuroscience, 159(2), 819-841.

Geiman, E. J., Zheng, W., Fritschy, J., \& Alvarez, F. J. (2002). Glycine and GABAA receptor subunits on Renshaw cells: Relationship with presynaptic neurotransmitters and postsynaptic gephyrin clusters. Journal of Comparative Neurology, 444(3), 275-289.

Gerfen, C. R., Paletzki, R., \& Heintz, N. (2013). GENSAT BAC cre-recombinase driver lines to study the functional organization of cerebral cortical and basal ganglia circuits. Neuron, 80(6), 1368-1383.

Gibson, G. D., Prasad, A. A., Jean-Richard-dit-Bressel, P., Yau, J. O., Millan, E. Z., Liu, Y., . . Power, J. M. (2018). Distinct Accumbens Shell Output Pathways Promote versus Prevent Relapse to Alcohol Seeking. Neuron, 98(3), 512-520.

Hammack, S. E., Mania, I., \& Rainnie, D. G. (2007). Differential expression of intrinsic membrane currents in defined cell tppes of the anterolateral bed nucleus of the stria terminalis. Journal of Neurophysiology, 98(2), 638-656.

Hazra, R., Guo, J.-D., Ryan, S. J., Jasnow, A. M., Dabrowska, J., \& Rainnie, D. G. (2011). A transcriptomic analysis of type I-III neurons in the bed nucleus of the stria terminalis. Molecular and Cellular Neurosciences, 46(4), 699-709.

Hendry, S., Jones, E., Emson, P., Lawson, D., Heizmann, C., \& Streit, P. (1989). Two classes of cortical GABA neurons defined by differential calcium binding protein immunoreactivities. Experimental Brain Research, 76(2), 467-472.

Herman, J. P., \& Larson, B. R. (2001). Differential regulation of forebrain glutamic acid decarboxylase mRNA expression by aging and stress. Brain Research, 912(1), 60-66.

This article is protected by copyright. All rights reserved. 
Hibino, H., Inanobe, A., Furutani, K., Murakami, S., Findlay, I., \& Kurachi, Y. (2010). Inwardly rectifying potassium channels: their structure, function, and physiological roles. Physiological Reviews, 90(1), 291-366.

Hopf, F. W., Martin, M., Chen, B. T., Bowers, M. S., Mohamedi, M. M., \& Bonci, A. (2007). Withdrawal from intermittent ethanol exposure increases probability of burst firing in VTA neurons in vitro. Journal of Neurophysiology, 98(4), 2297-2310.

Hossain, M. A., \& Wade, J. D. (2014). Synthetic relaxins. Current Opinion in Chemical Biology, 22, 47-55.

Hur, E., \& Zaborsky, L. (2005). Vglut2 afferents to the medial prefrontal and primary somatosensory cortices: a combined retrograde tracing in situ hybridisation. Journal of Comparative Neurology, 483, 351-373.

Inanobe, A., Fujita, A., Ito, M., Tomoike, H., Inageda, K., \& Kurachi, Y. (2002). Inward rectifier K+ channel Kir2.3 is localized at the postsynaptic membrane of excitatory synapses. American Journal of Physiology Cell Physiology, 282(6), C1396-1403.

Jennings, J. H., Sparta, D. R., Stamatakis, A. M., Ung, R. L., Pleil, K. E., Kash, T. L., \& Stuber, G. D. (2013). Distinct extended amygdala circuits for divergent motivational states. Nature, 496(7444), 224-228.

Ju, G., \& Swanson, L. W. (1989). Studies on the cellular architecture of the bed nuclei of the stria terminalis in the rat: I. Cytoarchitecture. Journal of Comparative Neurology, 280(4), 587-602.

Kania, A., Gugula, A., Grabowiecka, A., de Ávila, C., Blasiak, T., Rajfur, Z., . . Gundlach, A. L. (2017). Inhibition of oxytocin and vasopressin neuron activity in rat hypothalamic paraventricular nucleus by relaxin-3RXFP3 signalling. The Journal of Physiology, 595(11), 3425-3447.

Kawaguchi, Y. (1993). Physiological, morphological, and histochemical characterization of three classes of interneurons in rat neostriatum. Journal of Neuroscience, 13(11), 4908-4923.

Kemppainen, S., \& Pitkanen, A. (2000). Distribution of parvalbumin, calretinin, and calbindin-D28k immunoreactivity in the rat amygdaloid complex and colocalization with $\gamma$-aminobutyric acid. Journal of Comparative Neurology, 426, 441-467.

Kim, S. Y., Adhikari, A., Lee, S. Y., Marshel, J. H., Kim, C. K., Mallory, C. S., . . Deisseroth, K. (2013). Diverging neural pathways assemble a behavioural state from separable features in anxiety. Nature, 496(7444), 219-223.

Kocan, M., Sarwar, M., Hossain, M. A., Wade, J. D., \& Summers, R. J. (2014). Signalling profiles of H3 relaxin, H2 relaxin and $\mathrm{R} 3(\mathrm{~B} \Delta 23-27) \mathrm{R} / \mathrm{I5}$ acting at the relaxin family peptide receptor 3 (RXFP3). British Journal of Pharmacology, 171(11), 2827-2841.

Koob, G. F. (2003). Neuroadaptive mechanisms of addiction: studies on the extended amygdala. European Neuropsychopharmacology, 13(6), 442-452. 
Kudo, T., Uchigashima, M., Miyazaki, T., Konno, K., Yamasaki, M., Yanagawa, Y., . . . Watanabe, M. (2012). Three types of neurochemical projection from the bed nucleus of the stria terminalis to the ventral tegmental area in adult mice. Journal of Neuroscience, 32(50), 18035-18046.

La Salle, G., Paxinos, G., Emson, P., \& Ben-Ari, Y. (1978). Neurochemical mapping of GABAergic systems in the amygdaloid complex and bed nucleus of the stria terminalis. Brain Research, 155, 397-403.

Larriva-Sahd, J. (2006). Histological and cytological study of the bed nuclei of the stria terminalis in adult rat. II. Oval nucleus: Extrinsic inputs, cell types, neuropil, and neuronal modules. Journal of Comparative Neurology, 497(5), 772-807.

Lê, A., Funk, D., Coen, K., Tamadon, S., \& Shaham, Y. (2018). Role of K-opioid receptors in the bed nucleus of stria terminalis in reinstatement of alcohol seeking. Neuropsychopharmacology, 43(4), 838-850.

Leri, F., Flores, J., Rodaros, D., \& Stewart, J. (2002). Blockade of stress-induced but not cocaine-induced reinstatement by infusion of noradrenergic antagonists into the bed nucleus of the stria terminalis or the central nucleus of the amygdala. Journal of Neuroscience, 22, 5713-5718.

Liu, C., Eriste, E., Sutton, S. W., Chen, J., Roland, B., Kuei, C., . . . Lovenberg, T. W. (2003). Identification of relaxin-3/INSL7 as an endogenous ligand for the orphan G-protein-coupled receptor GPCR135. Journal of Biological Chemistry, 278, 50754-50764.

Lowenstein, D. H., Miles, M. F., Hatam, F., \& McCabe, T. (1991). Upregulation of calbindin-D28K mRNA in the rat hippocampus following focal stimulation of the perforant path. Neuron, 6, 627-633.

Ma, S., Blasiak, A., Olucha-Bordonau, F. E., Verberne, A. J., \& Gundlach, A. L. (2013). Heterogeneous responses of nucleus incertus neurons to corticotrophin-releasing factor and coherent activity with hippocampal theta rhythm in the rat. Journal of Physiology, 591(16), 3981-4001.

Ma, S., Bonaventure, P., Ferraro, T., Shen, P. J., Burazin, T. C. D., Bathgate, R. A. D., . . Gundlach, A. L. (2007). Relaxin-3 in GABA projection neurons of nucleus incertus suggests widespread influence on forebrain circuits via G-protein-coupled receptor-135 in the rat. Neuroscience, 144(1), 165-190.

Ma, S., Sang, Q., Lanciego, J. L., \& Gundlach, A. L. (2009). Localization of relaxin-3 in brain of Macaca fascicularis: identification of a nucleus incertus in primate. Journal of Comparative Neurology, 517, 856-872.

Mahler, S. V., \& Aston-Jones, G. S. (2012). Fos activation of selective afferents to ventral tegmental area during cue-induced reinstatement of cocaine seeking in rats. Journal of Neuroscience, 32(38), 13309-13326.

Marcinkiewcz, C. A., Mazzone, C. M., D'Agostino, G., Halladay, L. R., Hardaway, J. A., DiBerto, J. F., . . Kash, T. L. (2016). Serotonin engages an anxiety and fear-promoting circuit in the extended amygdala. Nature, 537(7618), 97-101. doi:10.1038/nature19318 
McDonald, A. J. (1983). Neurons of the bed nucleus of the stria terminalis: a golgi study in the rat. Brain Research Bulletin, 10, 111-120.

McDonald, A. J., Muller, J. F., \& Mascagni, F. (2002). GABAergic innervation of alpha type II calcium/calmodulin-dependent protein kinase immunoreactive pyramidal neurons in the rat basolateral amygdala. Journal of Comparative Neurology, 446(3), 199-218.

McFarland, K., Davidge, S. B., Lapish, C. C., \& Kalivas, P. W. (2004). Limbic and motor circuitry underlying footshock-induced reinstatement of cocaine-seeking behaviour. Journal of Neuroscience, 24, 15511560.

Miles, O. W., Thrailkill, E. A., Linden, A. K., May, V., Bouton, M. E., \& Hammack, S. E. (2017). Pituitary adenylate cyclase-activating peptide in the bed nucleus of the stria terminalis mediates stress-induced reinstatement of cocaine seeking in rats. Neuropsychopharmacology, 43(5), 978-986.

Moga, M. M., Saper, C. B., \& Gray, T. S. (1989). Bed nucleus of the stria terminalis: cytoarchitecture, immunohistochemistry, and projection to the parabrachial nucleus in the rat. Journal of Comparative Neurology, 283(3), 315-332.

Montpied, P., Weizman, A., Weizman, R., Kook, K. A., Morrow, A. L., \& Paul, S. M. (1993). Repeated swimstress reduces GABAA receptor $\alpha$ subunit mRNAs in the mouse hippocampus. Molecular Brain Research, 18(3), 267-272.

Nagano, Y., Kaneda, K., Maruyama, C., Ide, S., Kato, F., \& Minami, M. (2015). Corticotropin-releasing factor enhances inhibitory synaptic transmission to type III neurons in the bed nucleus of the stria terminalis. Neuroscience Letters, 600, 56-61.

Newman, S. W. (1999). The medial extended amygdala in male reproductive behavior a node in the mammalian social behavior network. Annals of the New York Academy of Sciences, 877(1), 242-257.

Nguyen, A. Q., Dela Cruz, J. A. D., Sun, Y., Holmes, T. C., \& Xu, X. (2016). Genetic cell targeting uncovers specific neuronal types and distinct subregions in the bed nucleus of the stria terminalis. Journal of Comparative Neurology, 524(12), 2379-2399.

Nichols, C., \& Lopatin, A. (1997). Inward rectifier potassium channels. Annual Review of Physiology, 59(1), 171191.

Olsen, C. M., Huang, Y., Goodwin, S., Ciobanu, D. C., Lu, L., Sutter, T. R., \& Winder, D. G. (2008). Microarray analysis reveals distinctive signaling between the bed nucleus of the stria terminalis, nucleus accumbens, and dorsal striatum. Physiological Genomics, 32(3), 283-298.

Ostrom, R. S., \& Insel, P. A. (2004). The evolving role of lipid rafts and caveolae in G protein-coupled receptor signaling: implications for molecular pharmacology. British Journal of Pharmacology, 143(2), 235-245.

This article is protected by copyright. All rights reserved. 
Paré, D., \& Smith, Y. (1993). Distribution of GABA immunoreactivity in the amygdaloid complex of the cat. Neuroscience, 57(4), 1061-1076.

Paxinos, G., \& Franklin, K. B. (2004). The mouse brain in stereotaxic coordinates: Gulf Professional Publishing.

Paxinos, G., \& Watson, C. (1986). The rat brain in stereotaxic atlas. London: Academic.

Pérez de Sevilla Müller, L., Do, M. T. H., Yau, K. W., He, S., \& Baldridge, W. H. (2010). Tracer coupling of intrinsically photosensitive retinal ganglion cells to amacrine cells in the mouse retina. Journal of Comparative Neurology, 518(23), 4813-4824.

Phelix, C. F., Liposits, Z., \& Paull, W. K. (1992). Monoamine innervation of bed nucleus of stria terminalis: an electron microscopic investigation. Brain Research Bulletin, 28, 949-965.

Player, A. N., Shen, L. P., Kenny, D., Antao, V. P., \& Kolberg, J. A. (2001). Single-copy gene detection using branched DNA (bDNA) in situ hybridization. Journal of Histochemistry and Cytochemistry, 49(5), 603612.

Pomrenze, M. B., Millan, E. Z., Hopf, F. W., Keiflin, R., Maiya, R., Blasio, A., . . Crawford, E. (2015). A transgenic rat for investigating the anatomy and function of corticotrophin releasing factor circuits. Frontiers in Neuroscience, 9, 487.

Poulin, J. F., Arbour, D., Laforest, S., \& Drolet, G. (2009). Neuroanatomical characterization of endogenous opioids in the bed nucleus of the stria terminalis. Progress in Neuropsychopharmacology and Biological Psychiatry, 33(8), 1356-1365.

Preston, R. J., Bishop, G. A., \& Kitai, S. T. (1980). Medium spiny neuron projection from the rat striatum: An intracellular horseradish peroxidase study. Brain Research, 183(2), 253-263.

Pruss, H., Derst, C., Lommel, R., \& Veh, R. W. (2005). Differential distribution of individual subunits of strongly inwardly rectifying potassium channels (Kir2 family) in rat brain. Brain Research Molecular Brain Research, 139(1), 63-79.

Randall, A., \& Tsien, R. (1997). Contrasting biophysical and pharmacological properties of T-type and R-type calcium channels. Neuropharmacology, 36(7), 879-893.

Robinson, R. B., \& Siegelbaum, S. A. (2003). Hyperpolarization-activated cation currents: from molecules to physiological function. Annual Review of Physiology, 65(1), 453-480.

Rodriguez-Sierra, O. E., Turesson, H. K., \& Pare, D. (2013). Contrasting distribution of physiological cell types in different regions of the bed nucleus of the stria terminalis. Journal of Neurophysiology, 110(9), 20372049.

Rodríguez-Sierra, O. E., Turesson, H. K., \& Pare, D. (2013). Contrasting distribution of physiological cell types in different regions of the bed nucleus of the stria terminalis. Journal of Neurophysiology, 110(9), 20372049.

This article is protected by copyright. All rights reserved. 
Ryan, P. J., Kastman, H. E., Krstew, E. V., Rosengren, K. J., Hossain, M. A., Churilov, L., . . Lawrence, A. J. (2013). Relaxin-3/RXFP3 system regulates alcohol-seeking. Proceedings of the National Academy of Sciences, 110(51), 20789-20794.

Sajdyk, T. J., Johnson, P. L., Fitz, S. D., \& Shekhar, A. (2008). Chronic inhibition of GABA synthesis in the bed nucleus of the stria terminalis elicits anxiety-like behavior. Journal of Psychopharmacology, 22(6), 633-641.

Sartor, G. C., \& Aston-Jones, G. (2012). Regulation of the ventral tegmental area by the bed nucleus of the stria terminalis is required for expression of cocaine preference. European Journal of Neuroscience, 36(11), 3549-3558.

Sequier, J. M., Hunziker, W., Andressen, C., \& Celio, M. R. (1990). Calbindin D-28k protein and mRNA localization in the rat brain. European Journal of Neuroscience, 2, 1118-1126.

Shabanpoor, F., Akhter Hossain, M., Ryan, P. J., Belgi, A., Layfield, S., Kocan, M., . . Bathgate, R. A. (2012). Minimization of human relaxin-3 leading to high-affinity analogues with increased selectivity for relaxin-family peptide 3 receptor (RXFP3) over RXFP1. Journal of Medicinal Chemistry, 55(4), 16711681.

Shaner, N. C., Campbell, R. E., Steinbach, P. A., Giepmans, B. N. G., Palmer, A. E., \& Tsien, R. Y. (2004). Improved monomeric red, orange and yellow fluorescent proteins derived from Discosoma sp. red fluorescent protein. Nature Biotechnology, 22(12), 1567-1572.

Silberman, Y., Matthews, R. T., \& Winder, D. G. (2013). A corticotropin releasing factor pathway for ethanol regulation of the ventral tegmental area in the bed nucleus of the stria terminalis. Journal of Neuroscience, 33(3), 950-960.

Silva, A. J., Stevens, C. F., Tonegawa, S., \& Wang, Y. (1992). Deficient hippocampal long-term potentiation in alpha-calcium-calmodulin kinase II mutant mice. Science, 257(5067), 201-206.

Simonds, S. E., Pryor, J. T., Ravussin, E., Greenway, F. L., Dileone, R., Allen, A. M., . . Cowley, M. A. (2014). Leptin mediates the increase in blood pressure associated with obesity. Cell, 159(6), 1404-1416.

Smith, C. M., Shen, P. J., Banerjee, A., Bonaventure, P., Ma, S., Bathgate, R. A. D., . . Gundlach, A. L. (2010). Distribution of relaxin-3 and RXFP3 within arousal, stress, affective, and cognitive circuits of mouse brain. Journal of Comparative Neurology, 518(19), 4016-4045.

Sun, N., \& Cassell, M. D. (1993). Intrinsic GABAergic neurons in the rat central extended amygdala. Journal of Comparative Neurology, 330(3), 381-404.

Szücs, A., Berton, F., Sanna, P. P., \& Francesconi, W. (2012). Excitability of jcBNST neurons is reduced in alcohol-dependent animals during protracted alcohol withdrawal. PLoS One, 7(8), e42313.

This article is protected by copyright. All rights reserved. 
Takamori, S., Rhee, J. S., Rosenmund, C., \& Jahn, R. (2001). Identification of differentiation-associated brainspecific phosphate transporter as a second vesicular glutamate transporter (VGLUT2). Journal of Neuroscience, 21(22), RC182-RC182.

Tanaka, H., lijima, N., Miyamoto, Y., Fukusumi, S., Itoh, Y., Ozawa, H., \& Ibata, Y. (2005). Neurons expressing relaxin 3/INSL 7 in the nucleus incertus respond to stress. European Journal of Neuroscience, 21, 16591670.

van der Westhuizen, E. T., Werry, T. D., Sexton, P. M., \& Summers, R. J. (2007). The relaxin family peptide receptor 3 activates extracellular signal-regulated kinase 1/2 through a protein kinase C-dependent mechanism. Molecular Pharmacology, 71(6), 1618-1629.

van Pett, K., Viau, V., Bittencourt, J. C., Chan, R. K. W., Li, H.-Y., Arias, C., . . Sawchenko, P. E. (2000). Distribution of mRNAs encoding CRF receptors in brain and pituitary of rat and mouse. Journal of Comparative Neurology, 428, 191-212.

Vranjkovic, O., Gasser, P. J., Gerndt, C. H., Baker, D. A., \& Mantsch, J. R. (2014). Stress-induced cocaine seeking requires a beta-2 adrenergic receptor-regulated pathway from the ventral bed nucleus of the stria terminalis that regulates CRF actions in the ventral tegmental area. Journal of Neuroscience, 34(37), 12504-12514.

Walker, L. C., Kastman, H. E., Koeleman, J. A., Smith, C. M., Perry, C. J., Krstew, E. V., . . Lawrence, A. J. (2017). Nucleus incertus corticotrophin-releasing factor 1 receptor signalling regulates alcohol seeking in rats. Addiction Biology, 22(6), 1641-1654.

Walker, L. C., Kastman, H. E., Krstew, E. V., Gundlach, A. L., \& Lawrence, A. J. (2017). Central amygdala relaxin3/relaxin family peptide receptor 3 signalling modulates alcohol seeking in rats. British Journal of Pharmacology, 174(19), 3359-3369.

Walter, A., Mai, J. K., Lanta, L., \& Görcs, T. (1991). Differential distribution of immunohistochemical markers in the bed nucleus of the stria terminalis in the human brain. Journal of Chemical Neuroanatomy, 4, 281298.

Wang, F., Flanagan, J., Su, N., Wang, L. C., Bui, S., Nielson, A., . . Luo, Y. (2012). RNAscope: a novel in situ RNA analysis platform for formalin-fixed, paraffin-embedded tissues. Journal of Molecular Diagnostics, 14(1), 22-29.

Wang, J., Fang, Q., Liu, Z., \& Lu, L. (2006). Region-specific effects of brain corticotropin-releasing factor receptor type 1 blockade on footshock-stress- or drug-priming-induced reinstatement of morphine conditioned place preference in rats. Psychopharmacology, 185(1), 19-28.

Wilkinson, T. N., Speed, T. P., Tregear, G. W., \& Bathgate, R. A. D. (2005). Coevolution of the relaxin-like peptides and their receptors. Ann N Y Acad Sci, 1041, 534-539.

This article is protected by copyright. All rights reserved. 
Wolansky, T., Pagliardini, S., Greer, J. J., \& Dickson, C. T. (2007). Immunohistochemical characterization of substance P receptor (NK1R)-expressing interneurons in the entorhinal cortex. Journal of Comparative Neurology, 502(3), 427-441.

Xu, X., Roby, K. D., \& Callaway, E. M. (2010). Immunochemical characterization of inhibitory mouse cortical neurons: three chemically distinct classes of inhibitory cells. Journal of Comparative Neurology, 518(3), 389-404. 


\section{Figure Legends}

Figure 1. Distribution of RXFP3+ neurons in mouse BNST.

(a-e) Photomicrographs of YFP immunofluorescence as a proxy for RXFP3 expression at different anterior/posterior (A/P) levels from bregma in the mouse BNST. RXFP3+ neurons are enriched in dorsal and posterior subdivisions of the BNST. Scale bar, $60 \mu \mathrm{m}$. (f) Graph depicting the rostral to caudal gradient of increasing numbers of RXFP3+ cells throughout the mouse BNST.

\section{Figure 2. RXFP3 and tdTomato mRNA expression in RXFP3-Cre/tdTomato mice.}

(a-c) RNAscope ${ }^{\circledR}$ multiplex fluorescent assay for RXFP3 (green) and tdTomato (magenta) mRNA expression surrounding DAPI-labelled nuclei (blue) at three representative levels in the BNST of RXFP3-Cre/tdTomato mice $(n=3)$. In agreement with reporter immunofluorescence, tdTomato and RXFP3 mRNA expression increased in a rostral to caudal gradient. A semi-quantitative system was used for quantifying the proportion of tdTomato+ cells co-expressing RXFP3, whereby cells that contained at least two fluorescent punctae were considered positive for that marker. Majority (80.5\%) of reporter-positive cells expressed RXFP3 mRNA, indicating high fidelity of fluorescent reporter expression in RXFP3-Cre:reporter mice. As a proportion of RXFP3+ cells, 91.1\% ( $\pm 3.1 \%$ ) co-expressed $t d T o m a t o$ mRNA. Scale bar, $10 \mu \mathrm{m}$.

\section{Figure 3. Neurochemical phenotype of RXFP3+ neurons in mouse BNST.}

(a-d) Triple-label immunohistochemistry for tdTomato, GABA, and calbindin. (a-c) Single channels for tdTomato (magenta), GABA (white), and calbindin (green), respectively; panel $\mathbf{d}$ is the merged image of panels a-c. Closed arrows denote examples of triple-labelled cells immunoreactive for all three markers (tdTomato+/GABA+/calbindin+). Open arrows denote examples of tdTomato+/GABA-/calbindin+ cells. (e-g) Double-label immunohistochemistry for tdTomato and CaMKIl $\alpha$. Panel e-f depict single channels for tdTomato (magenta) and CaMKIl $\alpha$ (green), respectively; panel $\mathbf{g}$ is the merged image of panels e and $\mathbf{f}$. Closed arrows denote examples of double-labelled cells. (h) RNAscope ${ }^{\circledR}$ multiplex fluorescent assay for RXFP3 (magenta) and VGluT2 (green) mRNA surrounding DAPI-labelled nuclei (blue). Each puncta represents a single mRNA molecule (Wang et al., 2012). A semi-quantitative system was used for quantifying the proportion of RXFP3+/VGluT2+ cells, whereby cells that contained at least two fluorescent punctae were considered positive for that marker. Scale bar, $40 \mu \mathrm{m}$.

This article is protected by copyright. All rights reserved. 
Figure 4. Electrophysiological properties identified BNST RXFP3+ cells as predominantly Type II neurons.

(a) RXFP3+ neurons in the dorsal BNST. The posterolateral (pIBNST), juxtacapsular (jxBNST), anteromedial (amBNST), and dorsolateral (dIBNST) divisions were identified by tdTomato and targeted for whole cell recordings. b) RXFP3+ neurons were classified based on their membrane voltage responses to both depolarizing and hyperpolarizing current steps according to Hammack \& Rainnie (2007). Type I, II, and III neurons were observed; atypical responses were classified as 'other'. (c) The majority of neurons were Type II (red) exhibiting prominent hyperpolarising currents and post-inhibitory rebound. (d) Recorded neurons were mapped across the BNST where there was a tendency for Type I neurons to be located in the posterior BNST. Note three neurons in panel $\mathbf{c}$ are not shown here.

Figure 5. BNST RXFP3+ neurons receive excitatory input.

(a) Immunohistochemical labelling of VGluT2 (magenta) closely apposing BNST RXFP3+ neurons (green), implying that they receive excitatory input. (b-c) Whole cell recordings in voltage clamp configuration demonstrated nearly all BNST RXFP3+ neurons exhibited spontaneous excitatory currents (sEPSCs, red) and inhibitory post synaptic currents (sIPSCs, blue). Together, excitatory and inhibitory spontaneous input was balanced, with regards to both the frequency $(\mathrm{Hz})$ and amplitude $(\mathrm{pA})$ of events being mostly equal within individual neurons in naïve mice.

Figure 6. The RXFP3 agonist, A2, hyperpolarizes BNST RXFP3+ neurons.

(a) Bath application of A2 (100 nM) hyperpolarized RXFP3+ neurons to suppress spontaneous action potential firing. With A2 wash out, this effect was reversed (break = $10 \mathrm{~min}$ ). (b) To confirm whether the A2-mediated hyperpolarization was a direct effect at RXFP3+ neurons, this experiment was repeated in the presence of the voltage activated sodium channel blocker, tetrodotoxin (TTX). A2 hyperpolarized this RXFP3+ neuron in these conditions. (c) A2 predominantly hyperpolarised RXFP3+ neurons, an effect that persisted in the presence of $\operatorname{TTX}(* \mathrm{p}<0.05$ vs TTX alone, paired t-test).

Figure 7. The RXFP3 agonist, A2, modulates presynaptic input to BNST RXFP3+ neurons. 
(a) Traces from a single BNST RXFP3+ neuron in which A2 decreased the frequency of spontaneous inhibitory post synaptic currents (SIPSCs), illustrated by a rightward shift of the inter-event interval in cumulative fraction (frac.) plots. Spontaneous IPSCs returned to baseline levels with wash out of A2. (b) Traces from a single BNST RXFP3+ neuron in which A2 increased the frequency of sIPSCS, illustrated by a leftward shift of the inter-event interval in cumulative fraction (frac.) plots. sIPSCs returned to baseline levels with wash out of A2 and were blocked by the $G A B A_{A}$ receptor antagonist, gabazine (GBZ). (c) Traces from a single BNST RXFP3+ neuron in which A2 decreased the frequency of spontaneous EPSCs, illustrated by a rightward shift of the inter-event interval in cumulative fraction plot. (d) Across neurons, $A 2$ either increased or decreased GABA release onto BNST RXFP3+ neurons. (e) A2 also impacted spontaneous glutamate release onto BNST RXFP3+ neurons; like IPSCS, the result was either a decrease or increase in the frequency of EPSC events that in each case was reversed with A2 wash out.

Figure 8. BNST RXFP3+ neurons are modulated by CRF.

(a) Immunohistochemical labelling of CRF (magenta) was observed in fibres that closely appose (arrows) BNST RXFP3+ neurons (green). (b) In this single BNST RXFP3+ neuron the membrane potential ( $\mathrm{mV}$, between spikes) and frequency of action potential (AP) firing of BNST RXFP3+ neurons increased with bath application of CRF (100-300 nM). (c) Across the population of RXFP3+ neurons tested $(n=11), 6 / 11$ depolarized $(-59.8 \pm 3$ to $55.6 \pm 2.7 \mathrm{mV}$ ) with CRF exposure, in 2 of these neurons action potential threshold was met and firing rates increased from $0.6 \pm 0.5$ to $1.6 \pm 1 \mathrm{~Hz}$, indicating that these neurons are responsive to CRF.

Figure 9. Chronic stress selectively alters ion channel expression in BNST RXFP3+ neurons.

(a) A swim stress protocol ( 6 min daily for 5 days) was performed; 24 hours after the final session, brain slices were collected. All electrophysiological assays were repeated in BNST RXFP3+ neurons. (b) Chronic swim stress appeared to alter ion channel expression/insertion in BNST RXFP3+ neurons such that the proportion of Type II neurons decreased, and Type III and 'other' classified neurons increased. (c) This change in current voltage responses with chronic swim stress did not alter the resting membrane potential of RXFP3+ neurons (naïve cohort, orange squares; swim stress cohort, dark grey circles). (d) The location of recorded RXFP3+ neurons within the BNST mirrored those in the naive cohort (Figure 1c). (e) In measuring presynaptic input to RXFP3+ neurons, there was no difference in the ratio of spontaneous excitatory and inhibitory post synaptic currents (sEPSCs and sIPSCs, respectively) of individual cells between the naïve (orange squares) and swim stress (dark 
grey circles) cohorts. (f) The decay time of sIPSCs was lengthened, as demonstrated in these two representative neurons where IPSCs where normalised for amplitude, averaged, and compared. (g) Across the naïve and stress cohorts, decay time significantly increased ( ${ }^{*} p<0.05$ vs naïve, $t$ test). (h $\&$ i) There was no difference in how A2 altered sIPSC (h) and SEPSC (i) frequency or amplitude between the cohorts. (j) Similarly, chronic stress did not alter the proportion, magnitude or variability of A2-evoked hyperpolarization $(n=8)$ or CRF-evoked depolarization $(n=5)$ in RXFP3+ neurons. 

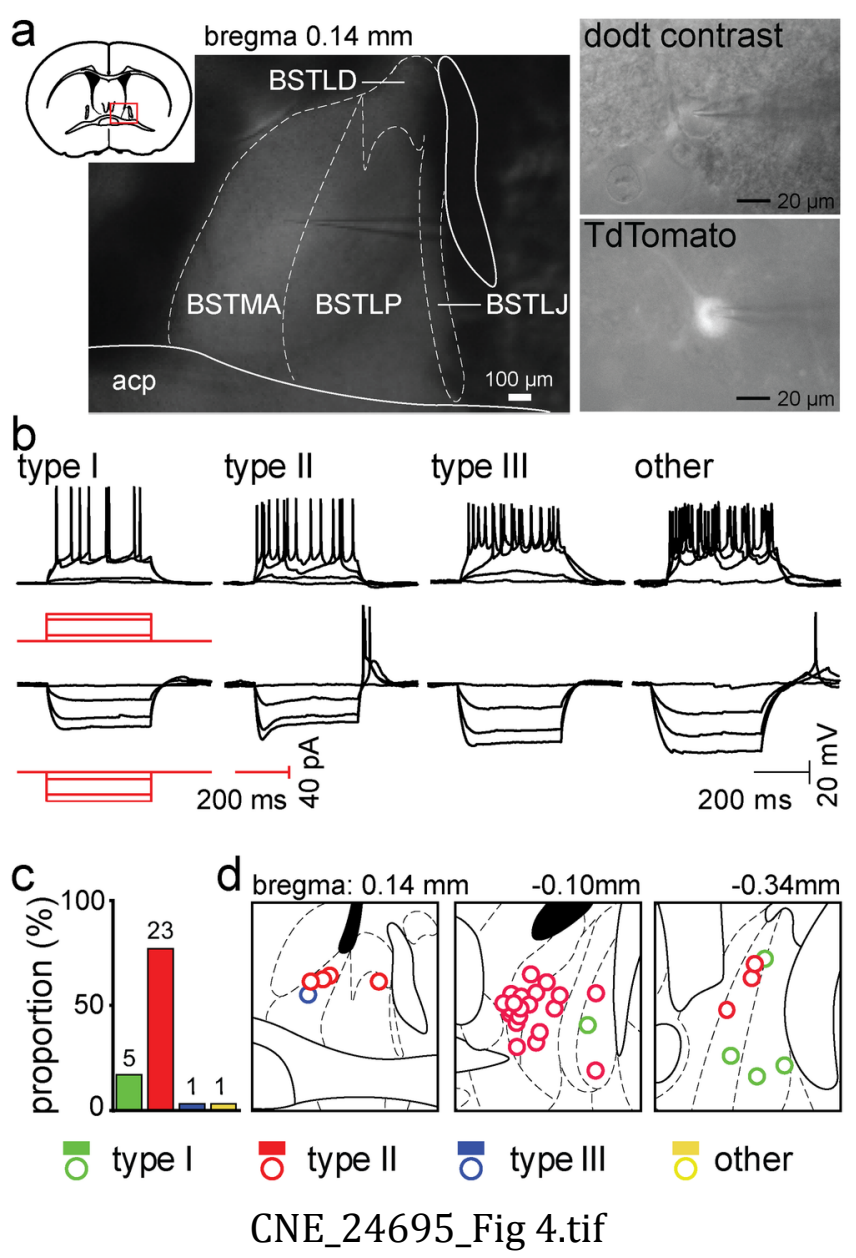

This article is protected by copyright. All rights reserved. 


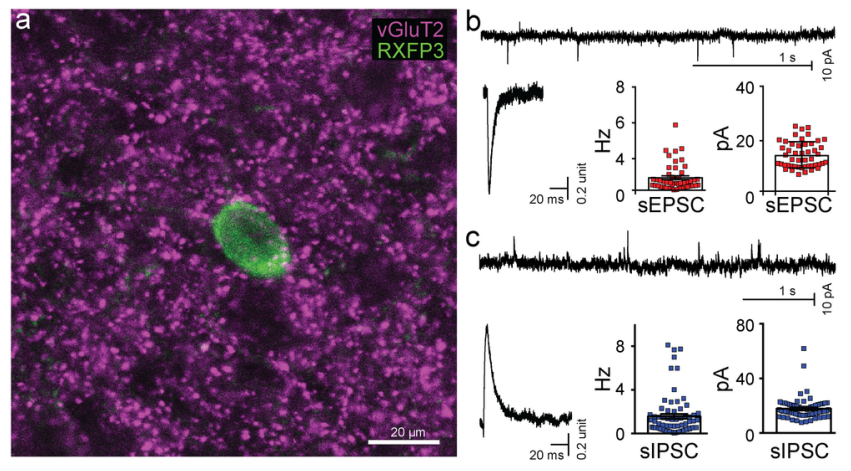

CNE_24695_Fig 5.tif

This article is protected by copyright. All rights reserved. 

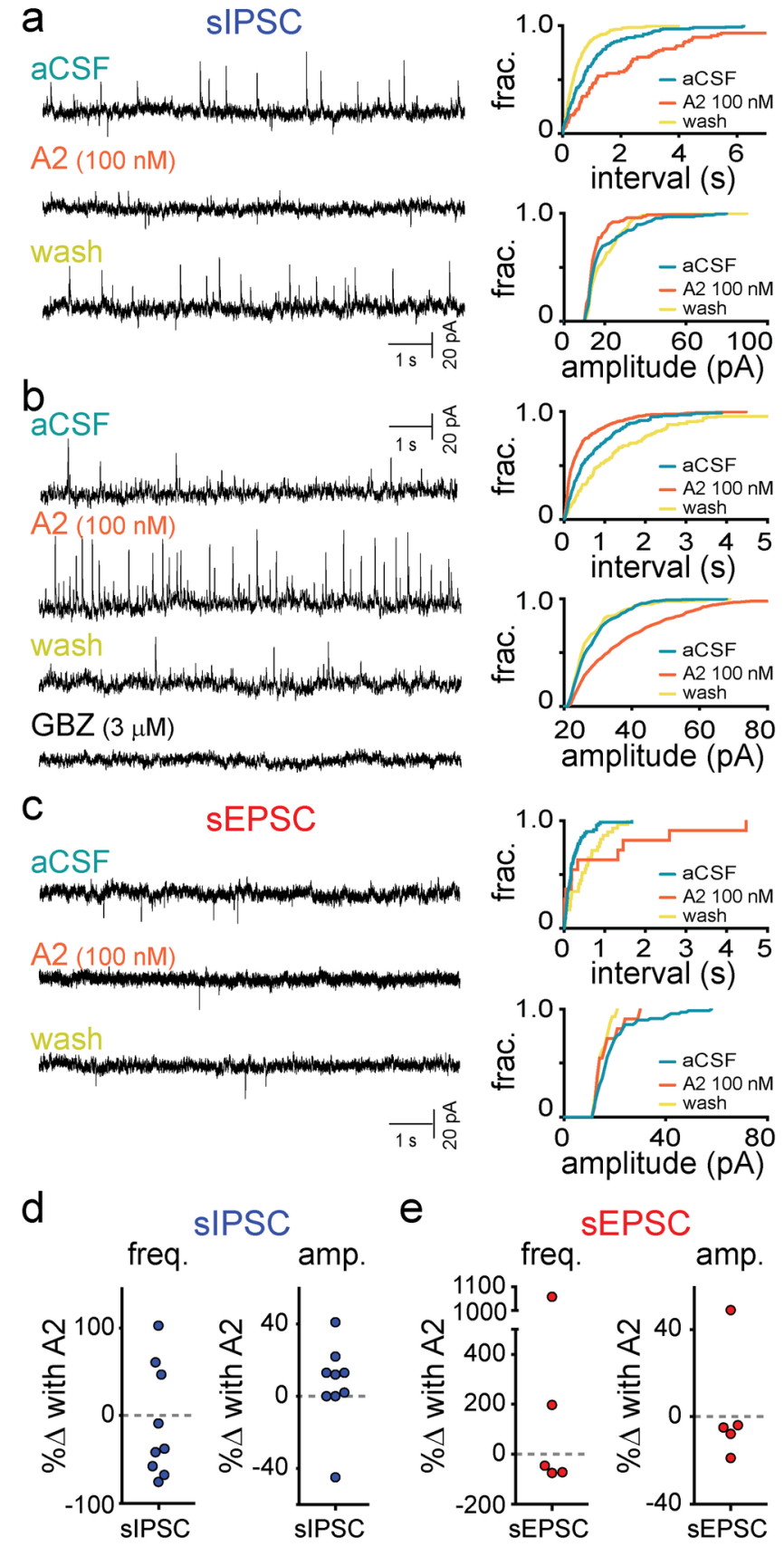

CNE_24695_Fig 7.tif 


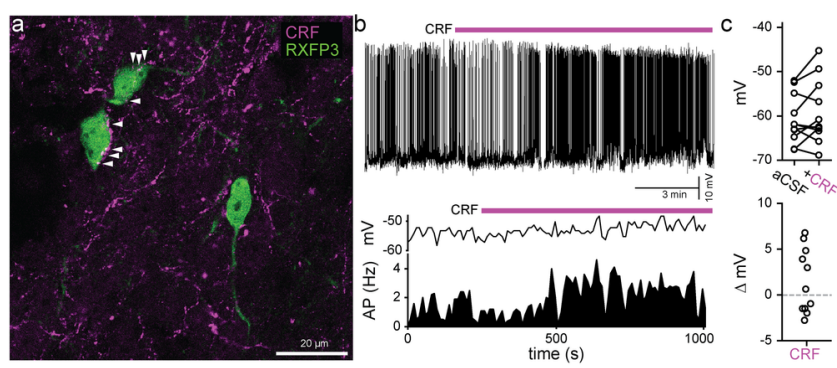

CNE_24695_Fig 8.tif

This article is protected by copyright. All rights reserved. 
a Swim stress protocol

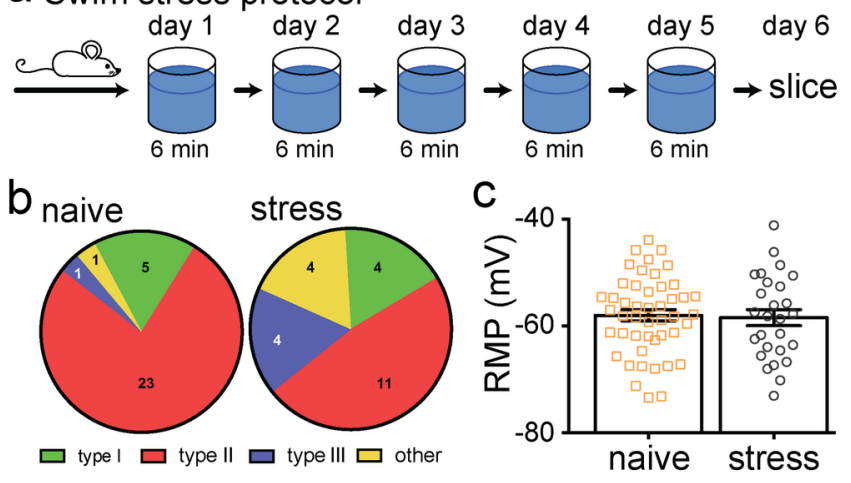

$\mathrm{d}_{\text {bregma: } 0.14 \mathrm{~mm}} \quad-0.10 \mathrm{~mm} \quad-0.34 \mathrm{~mm} \mathrm{e}$

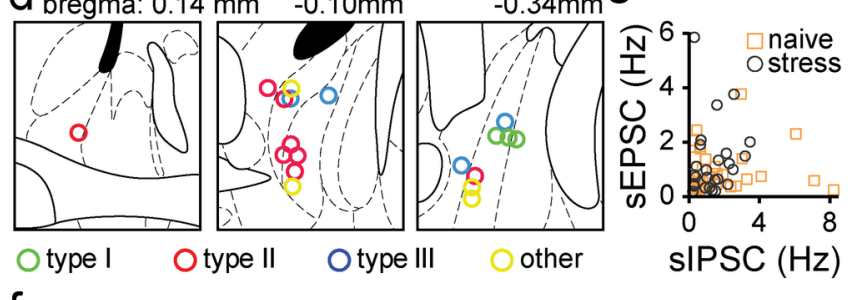

f naive

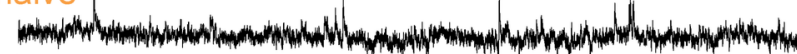
stress

S.M.

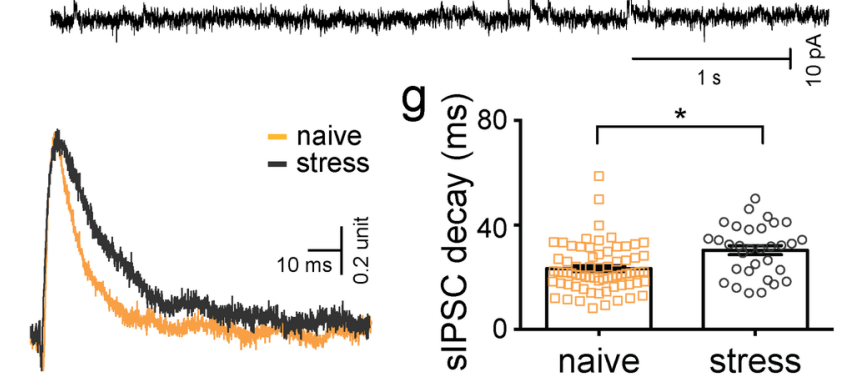

h sIPSC i $\quad$ sEPSC j RMP

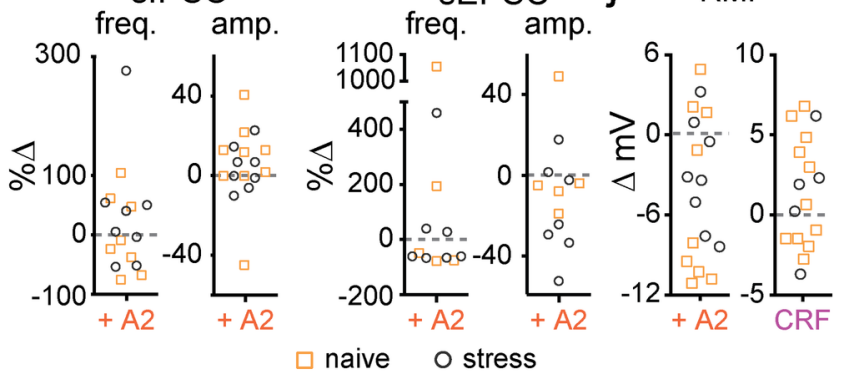

CNE_24695_Fig 9.tif

This article is protected by copyright. All rights reserved. 


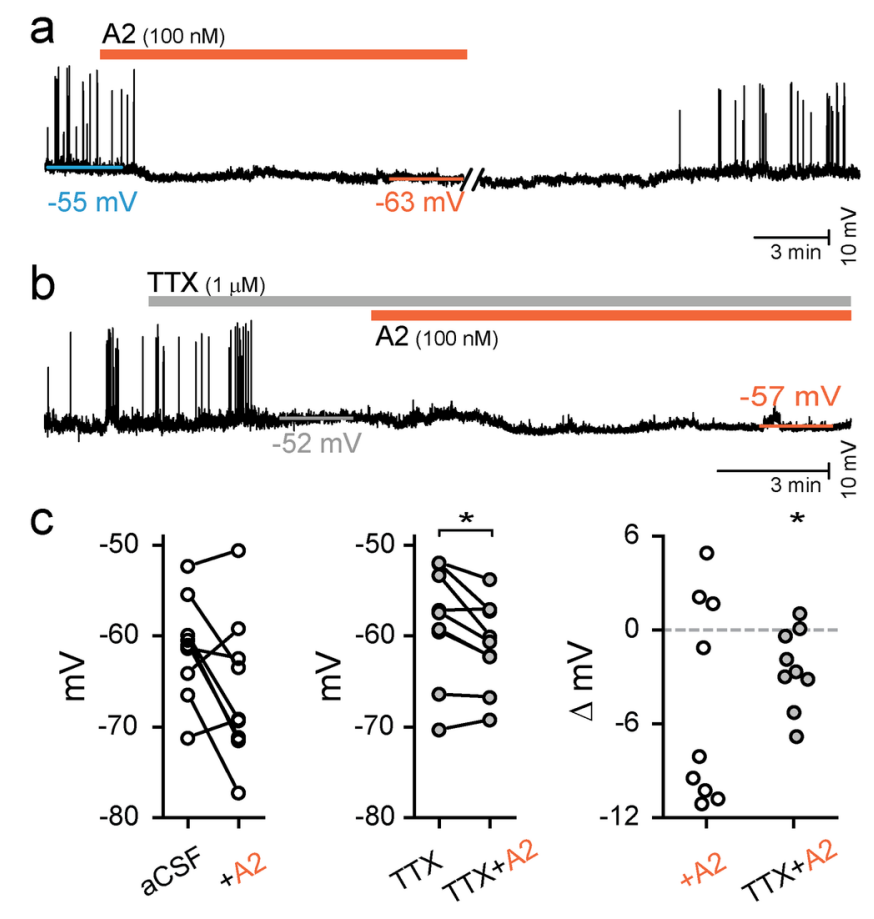

CNE_24695_Fig 6.tif 

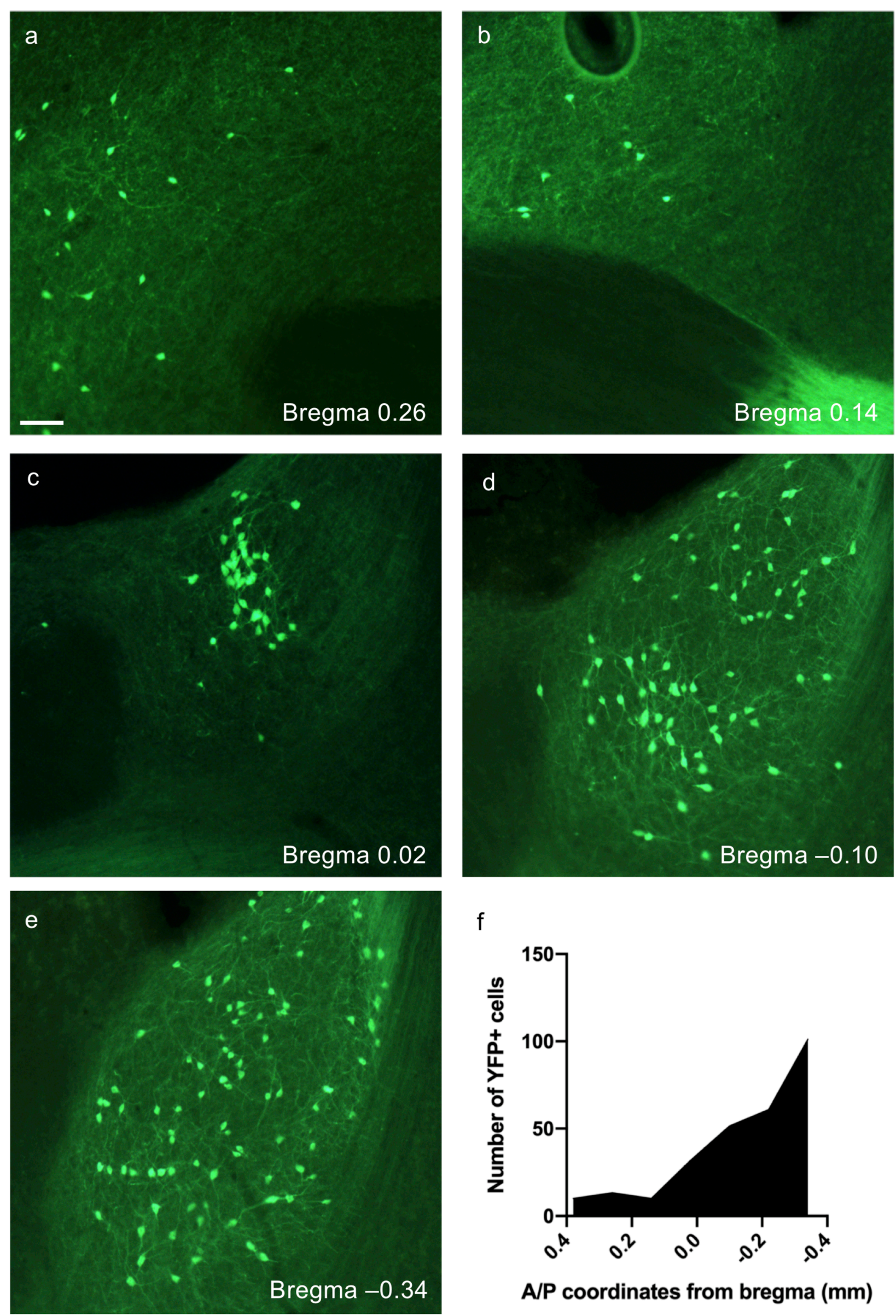

CNE_24695_Figure 1.tif

This article is protected by copyright. All rights reserved. 

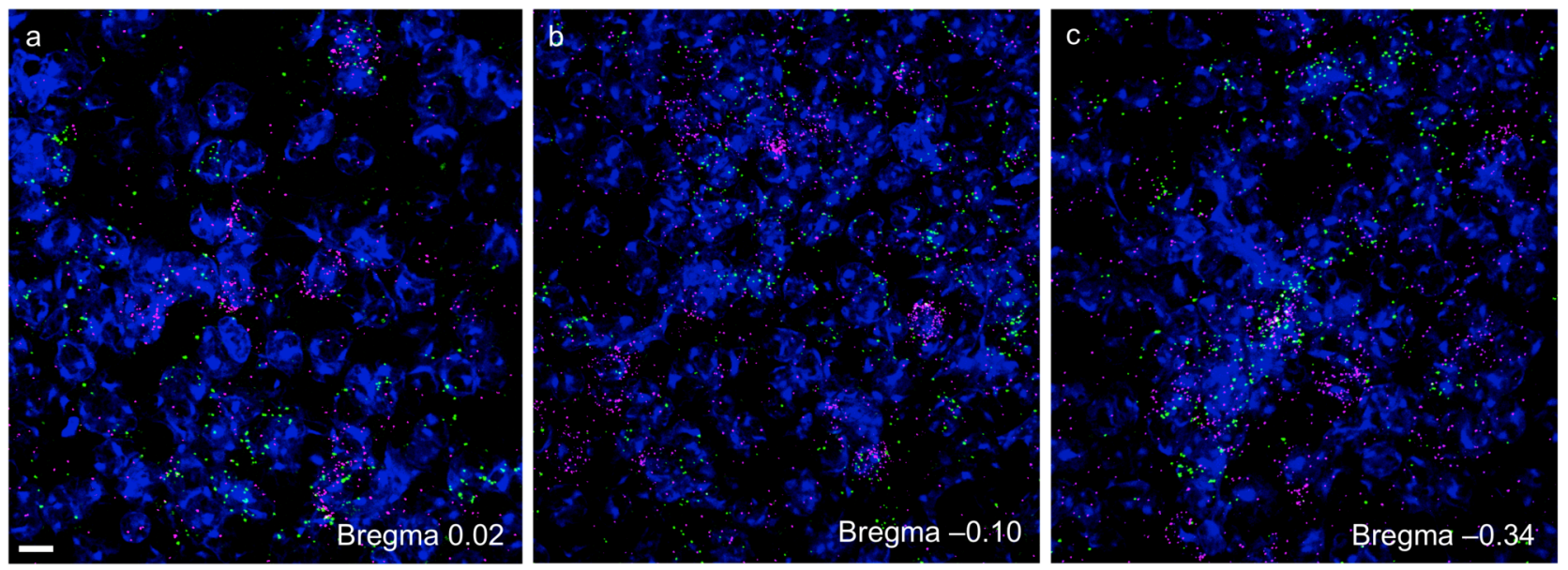

CNE_24695_Figure 2.tif

This article is protected by copyright. All rights reserved. 

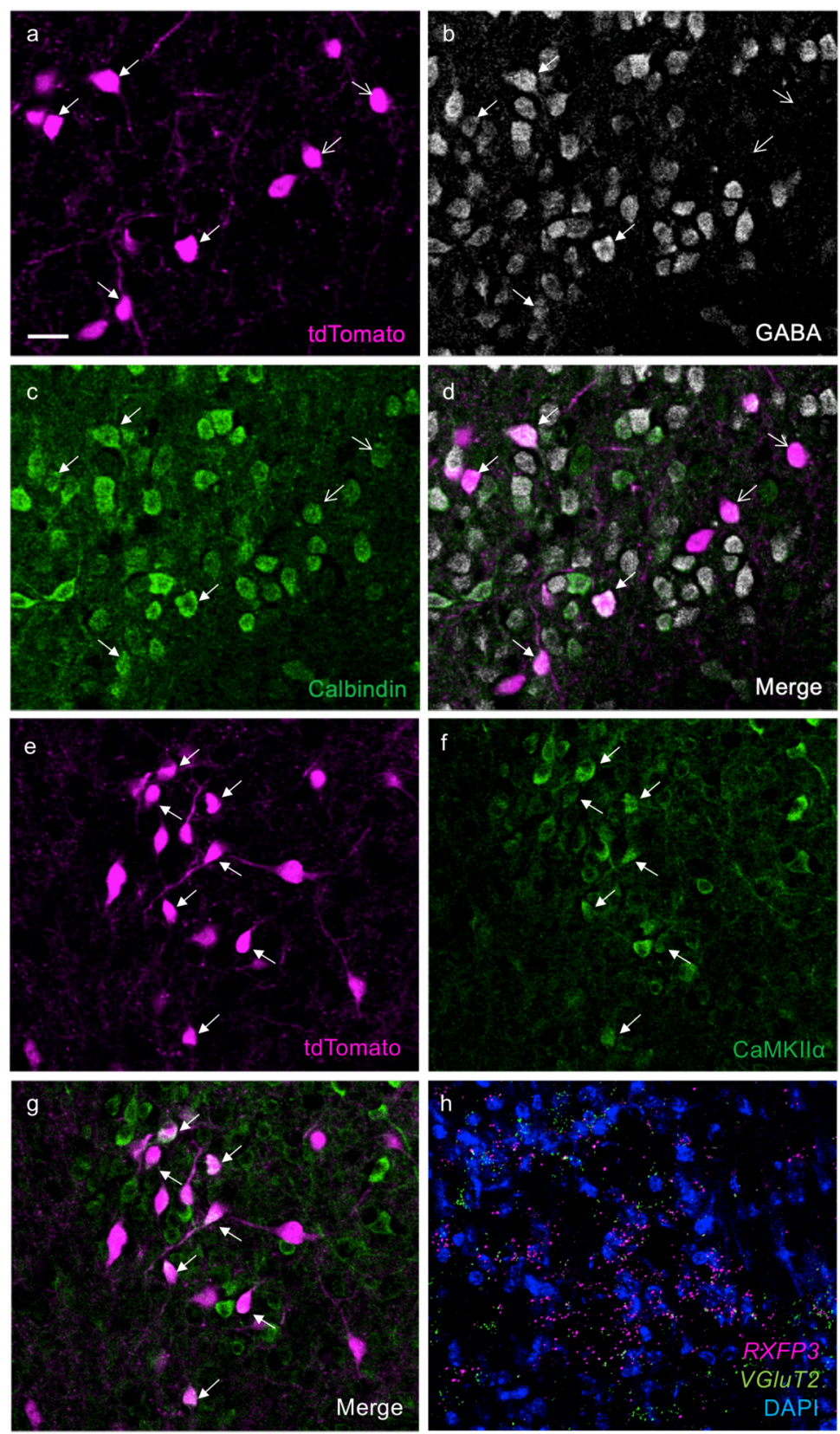

CNE_24695_Figure 3.tif 
We have characterized the distribution, neurotransmitter phenotype, and electrophysiological properties of neurons expressing relaxin family peptide receptor 3 (RXFP3) in the bed nucleus of the stria terminalis (BNST) using RXFP3-Cre reporter mice. BNST RXFP3+ neurons are neurochemically heterogeneous and can be classified into four basic types in terms of basal firing properties. Chronic stress alters the relative proportions of different BNST RXFP3+ neuronal subtypes consistent with experience-dependent plasticity. 

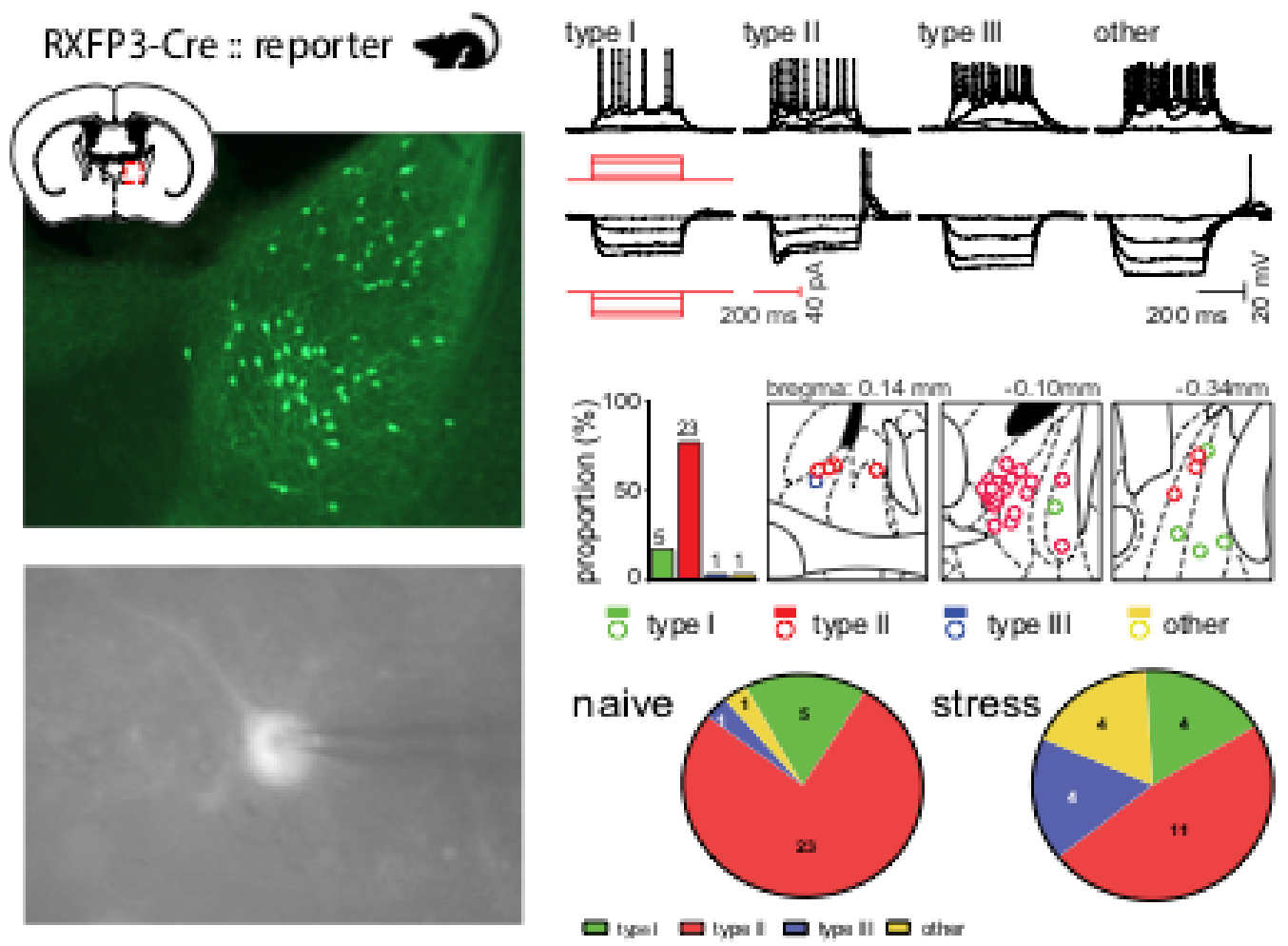

CNE_24695_Graphical Abstract_final.tiff

This article is protected by copyright. All rights reserved. 


\begin{tabular}{|c|c|c|c|c|c|c|c|}
\hline Antigen & Host & Immunogen & Dilution & Type & Source & RRID & Cat. No. \\
\hline GFP & Chicken & $\begin{array}{l}\text { Recombinant full } \\
\text { length protein } \\
\text { corresponding to GFP }\end{array}$ & 1:1000 & Polyclonal & Abcam & AB_300798 & ab13970 \\
\hline GABA & Rabbit & $\begin{array}{l}\text { GABA conjugated to } \\
\text { bovine serum albumin }\end{array}$ & 1:1000 & Polyclonal & $\begin{array}{l}\text { Sigma } \\
\text { Aldrich }\end{array}$ & AB_477652 & A2052 \\
\hline vGluT2 & Rabbit & $\begin{array}{l}\text { Strep-Tag }{ }^{\circledR} \text { fusion } \\
\text { protein of rat vGluT2 } \\
\text { (aa } 510-582 \text { ) }\end{array}$ & 1:1000 & Polyclonal & $\begin{array}{l}\text { Synaptic } \\
\text { Systems }\end{array}$ & AB_887883 & 135403 \\
\hline Parvalbumin & Mouse & $\begin{array}{l}\text { Frog muscle } \\
\text { parvalbumin }\end{array}$ & 1:2000 & Monoclonal & $\begin{array}{l}\text { Sigma } \\
\text { Aldrich }\end{array}$ & AB_477329 & P3088 \\
\hline Calbindin & Goat & $\begin{array}{l}\text { Residues } 242-261 \text { at } \\
\text { the C-terminus of } \\
\text { human calbindin D28k }\end{array}$ & $1: 800$ & Polyclonal & $\begin{array}{l}\text { Santa } \\
\text { Cruz }\end{array}$ & $A B \_634520$ & sc7691 \\
\hline Calretinin & Rabbit & $\begin{array}{l}\text { Human recombinant } \\
\text { calretinin }\end{array}$ & $1: 2000$ & Polyclonal & Swant & AB_2619710 & 7697 \\
\hline CaMKIl $\alpha$ & Mouse & $\begin{array}{l}\text { Partially purified rat } \\
\text { CaMKIl } \alpha\end{array}$ & 1:1000 & Monoclonal & $\begin{array}{l}\text { EMD } \\
\text { Millipore }\end{array}$ & AB_309787 & 05532 \\
\hline
\end{tabular}

Table 1. Primary antibodies used for IHC. Where RXFP3-Cre/YFP mice were used, primary antibodies were added in conjunction with the chicken anti-GFP primary antibody. Note that the tdTomato protein does not require immunoamplification. CaMKIl $\alpha$, calcium/calmodulin-dependent protein kinase II $\alpha$; GABA, $\gamma$-amino butyric acid; GFP, green fluorescent protein; vGluT2, vesicular glutamate transporter 2 


\begin{tabular}{|c|c|c|c|c|c|}
\hline Antibody & Host & Dilution & Source & RRID & Cat. No. \\
\hline $\begin{array}{l}\text { AF488-conjugated anti-chicken } \\
\text { IgG }\end{array}$ & Donkey & $1: 200$ & Jackson ImmunoResearch & AB_2340375 & 703545155 \\
\hline $\begin{array}{l}\text { AF647-conjugated anti-rabbit } \\
\text { IgG }\end{array}$ & Donkey & $1: 200$ & Invitrogen & AB_2536183 & A31573 \\
\hline $\begin{array}{l}\text { AF488-conjugated anti-mouse } \\
\text { IgG }\end{array}$ & Donkey & $1: 200$ & Invitrogen & AB_141607 & A21202 \\
\hline AF647-conjugated anti-goat IgG & Donkey & $1: 200$ & Invitrogen & AB_141844 & A21447 \\
\hline $\begin{array}{l}\text { AF594-conjugated anti-rabbit } \\
\text { IgG }\end{array}$ & Donkey & $1: 200$ & Invitrogen & AB_141637 & A21207 \\
\hline AF488-conjugated anti-goat IgG & Donkey & $1: 200$ & Invitrogen & AB_142672 & A11055 \\
\hline Biotinylated anti-guinea pig IgG & Goat & $1: 500$ & Vector Laboratories & AB_2336132 & BA7000 \\
\hline AF594-conjugated streptavidin & - & $1: 400$ & Invitrogen & Unavailable & S32356 \\
\hline
\end{tabular}

Table 2. Secondary antibodies used for immunohistochemistry.

This article is protected by copyright. All rights reserved. 


\begin{tabular}{ll}
\hline A/P coordinates from bregma $(\mathrm{mm})$ & YFP+ cell counts \\
\hline 0.38 & $10.1 \pm 0.9$ \\
0.26 & $13.3 \pm 0.7$ \\
0.14 & $10.0 \pm 1.1$ \\
0.02 & $31.8 \pm 1.5$ \\
-0.10 & $51.6 \pm 3.7$ \\
-0.22 & $60.9 \pm 4.9$ \\
-0.34 & $101.1 \pm 3.8$ \\
\hline
\end{tabular}

Table 3. Absolute counts per hemisphere of YFP+ cells in the BNST. Counts were made bilaterally at each anterior/posterior (A/P) bregma level throughout the BNST in 5 brains and averaged across animals. Data are presented as mean number of YFP+ cells \pm SEM.

This article is protected by copyright. All rights reserved. 


\begin{tabular}{ll}
\hline Marker & Percentage co-expression (\%) \\
\hline GABA+ & $48( \pm 1)$ \\
CB+ & $25( \pm 4)$ \\
GABA+/CB+ & $16( \pm 3)$ \\
GABA+/CB- & $33( \pm 6)$ \\
GABA-/CB+ & $9( \pm 3)$ \\
\hline
\end{tabular}

Table 4. Percentage co-expression of GABA and/or CB as a proportion of RXFP3+ cells. Data are expressed as mean percentages of co-labelled cells \pm SEM. Counts were based on pooled totals of cells from every fourth section through serial BNST sections ( $n=4-5$ mice). CB, calbindin; GABA, $\gamma$-amino butyric acid.

This article is protected by copyright. All rights reserved. 